\title{
G-Quadruplexes as Potential Therapeutic Targets for Embryonal Tumors
}

\author{
Tarek Shalaby ${ }^{1, *}$, Giulio Fiaschetti ${ }^{1}$, Kazuo Nagasawa ${ }^{2}$, Kazuo Shin-ya ${ }^{3}$, \\ Martin Baumgartner ${ }^{1}$ and Michael Grotzer ${ }^{1}$
}

1 Division of Oncology, University Children's Hospital of Zurich, Zurich 8032, Switzerland

2 Department of Biotechnology and Life Science, Faculty of Technology, Tokyo University of Agriculture and Technology, Koganei, Tokyo 184-8588, Japan

3 National Institute of Advanced Industrial Science and Technology (AIST), Tokyo 135-0064, Japan

* Author to whom correspondence should be addressed; E-Mail: tarek.shalaby@kispi.uzh.ch; Tel.: +41-446-348-820; Fax: +41-446-348-859.

Received: 30 August 2013; in revised form: 18 September 2013 / Accepted: 25 September 2013 / Published: 10 October 2013

\begin{abstract}
Embryonal tumors include a heterogeneous group of highly malignant neoplasms that primarily affect infants and children and are characterized by a high rate of mortality and treatment-related morbidity, hence improved therapies are clearly needed. G-quadruplexes are special secondary structures adopted in guanine (G)-rich DNA sequences that are often present in biologically important regions, e.g. at the end of telomeres and in the regulatory regions of oncogenes such as MYC. Owing to the significant roles that both telomeres and MYC play in cancer cell biology, G-quadruplexes have been viewed as emerging therapeutic targets in oncology and as tools for novel anticancer drug design. Several compounds that target these structures have shown promising anticancer activity in tumor xenograft models and some of them have entered Phase II clinical trials. In this review we examine approaches to DNA targeted cancer therapy, summarize the recent developments of G-quadruplex ligands as anticancer drugs and speculate on the future direction of such structures as a potential novel therapeutic strategy for embryonal tumors of the nervous system.
\end{abstract}

Keywords: embryonal tumors; G-quadruplexes; MYC; telomeres 


\section{Introduction}

Embryonal tumors most commonly occur in the first few years of life and account for more than $25 \%$ of childhood malignancies [1]. They include medulloblastoma (MB), neroblastoma (NB), soft tissue sarcomas, nephroblastoma (Wilm's tumor), bone tumors, retinoblastoma, hepatoblastoma, germ-cell tumors and various other rare subtypes. This broad group of childhood tumors differs fundamentally from adult onset cancers, both in their cell biology and their tissue environment. Embryonal tumors originate from immature tissue as a result of the aberrant proliferation of early precursor cells and their morphological appearance resembles that of tissues in the developing embryo and fetus [2,3]. Most embryonal tumors are unfavorable malignant tumors with a relatively high proportion of children dying due to current therapy resistant disease. It is therefore likely that improved treatments for these cancers will only be possible when the molecular events that are specific to the tumors are better understood.

$\mathrm{MB}$ and NB are malignant embryonal tumors of the central and peripheral nervous systems, respectively [4,5]. Childhood $\mathrm{MB}$ is a cancer of the cerebellum, while NB arises in the sympathetic nervous system showing heterogeneous biological and clinical features. Both MB and NB belong to the most challenging oncologic diseases of childhood that often show poor clinical prognosis. Despite intensive multimodal therapy, including surgery, chemotherapy and radiation, both high-risk NB and metastatic MB frequently acquire therapy resistance with fatal clinical outcomes. Moreover, many of the survivors suffer the risk of severe consequences from the intensive treatment; in particular children with $\mathrm{MB}$ who often experience long-term side effects mainly due to radiation therapy to the developing brain with high risks of severe morbidity even if cured of the tumor. Hence the development of novel therapeutic approaches based on identification of specific targets seems the most promising way forward to a better outcome for children with these unfavorable malignant tumors [6,7].

Anticancer agents that target DNA are some of the most effective agents in clinical use and have produced significant increases in the survival of cancer patients but, unfortunately, they are extremely toxic. Consequently, much effort has been put into finding agents that are more selective and there is considerable excitement that the identification of cancer-specific DNA targets will yield a new generation of less toxic therapeutics [8]. Secondary DNA structures, such as G-quadruplex nucleic acids, have recently emerged as a new class of molecular targets for DNA-interactive compounds. These elements are nonclassical four-stranded secondary structures arising from the folding of a single DNA strand that comprises stretches of tandem guanines. G-quadruplexes are found to be present in biologically important regions of DNA that are essential for cancer cells to proliferate indefinitely such as telomere and regulatory regions of oncogenes. Owing to the abundance of detailed information available regarding their thermodynamic stabilities [9] and their potential anticancer activities, G-quadruplexes are viewed as emerging therapeutic targets in oncology [10-14]. Several compounds that target these structures have shown promising anticancer activity in tumor xenograft models and some of them have entered Phase II clinical trials. This review examines approaches to DNA targeted therapy, describes recent developments of G-quadruplex ligands as anticancer drugs and discusses their potential as therapeutic targets, for embryonal tumors of the nervous system. 


\section{DNA as a Target for Anticancer Therapy}

DNA has played a role as a successful molecular target for many of the drugs that have been used for decades in cancer therapeutics and there are good reasons to expect DNA will continue to be a clinically important target for many years to come [8]. Anticancer chemotherapies that target DNA are some of the most effective drugs in the clinical use and have produced significant increases in the survival of pediatric cancer patients [15]. Most of these chemotherapeutic are DNA-damaging agents that have been proven to cause relative potent destruction of tumor cells. However, the clinical potential of DNA-damaging agents is undermined by the adverse side effects and increased risk of secondary cancers that are consequences of the agents' genotoxicity [16].

DNA integrity is critical for proper cellular function and proliferation. DNA damage is detected by cell-cycle checkpoint proteins, whose activation induces cell-cycle arrest to prevent the transmission of damaged DNA during mitosis. If damaged DNA cannot be properly repaired cell death usually results [17]. The rationale for targeting DNA to treat cancer is based on the facts that rapidly proliferating tumor cells depend upon DNA integrity more than normal quiescent cells [16].

DNA-damaging compounds with anticanceractivity were shown to target DNA either directly or through inhibition of enzymes that control DNA integrity or provide building blocks for DNA. There are several established therapeutic modalities targeting DNA: (i) antimetabolites which are DNA antagonists that exert their activity by blocking nucleotide metabolism pathways, such as capecitabine, floxuridine, and gemcitabin as well as the canonical folic acid antagonists such as methotrexate; (ii) alkylation agents that cause direct DNA damage. These include compounds that directly modify DNA bases, intercalate between bases, or form cross-links in DNA, such as nitrogen mustards and their derivatives that directly alkylate DNA on purine bases, leading to stalled replication fork progression and subsequent cell death via apoptosis. Other DNA alkylators which are currently used in clinical therapeutics include cyclophosphamide, chlorambucil, melphalan, carmustine, lomustine, semustine, dacarbazine and temozolomide [8]. Temozolomide is a monoalkylation drug which methylates guanine residues in DNA. The most potent and efficacious agents, however such as chlorambucil and melphalan, were found to crosslink the two complementary strands of DNA, rather than just alkylating one strand. Intercalators such as actinomycins bind DNA and inhibit the activity of many enzymes that use DNA as a substrate; (iii) in addition to alkylating agents antitumor antibiotics such as doxorubicin, bleomycin and distamycin have made an important impact on the treatment of cancer patients; (iv) among the most widely and successfully used anticancer agents today are nonspecific DNA-damaging chemicals, including inhibitors of topoisomerases (TOPO) I and II and agents causing covalent modification of DNA such as mitomycin C, streptozotocin and platinum compounds [16]. Natural products which alkylate DNA bases such as mitomycin C and streptozotocin crosslink DNA on opposite strands of the double helix, resulting in a more potent effect against cancer cells compared to monofunctional alkylation. The discovery of the alkylating agent-like platinum agents such as cisplatin had a significant positive impact on anticancer drug research. Indeed, cisplatin therapy can cure over $90 \%$ of all testicular cancer cases and also has good efficacy in the treatment of ovarian, bladder, head and neck, and cervical cancers [17,18]. DNA remains a promising target for anticancer drug development, but DNA damage to normal cells as well is not a prerequisite for anti-tumor activity. The focus until recently was on double-stranded (ds) DNA structures that have been 
known for 60 years [19]. Chemotherapeutical drugs that are currently used in cancer therapy are thought to act through the unspecific recognition of highly 'active' ds DNA in cancer cells that is in replication at high frequency and therefore relatively exposed to recognition by DNA targeting molecules. Following DNA recognition by these compounds, the subsequent interaction involves either intercalation of the ligand's planar aromatic rings between two adjacent DNA base pairs, or major or minor-groove binding (Table 1). However, nonspecific binding through electrostatic interactions with the negatively charged sugar-phosphate backbone frequently occurs. Consequently, this has driven interest in the targeting of unusual, non-canonical structures in DNA, in order to achieve selectivity while potentially reducing adverse side effects [20]. One DNA structure that has attracted significant attention as an anticancer target is the G-quadruplex [16]. Compared to duplex DNA, G-quadruplexes have much more compact structures that contain well-defined binding sites for small molecules. It has been proposed that the different structural morphology of G-quadruplex DNA, will provide different G-quadruplex recognition site for binding different G-quadruplex interacting ligands. Small organic molecules have been proposed to interact noncovalently with G-quadruplex through stacking on the ends of the G-tetrad core, groove binding, taking the place of one or more strands in the core, interacting with the backbone (core and loops), or interacting with the loop bases These G-quadruplex elements are often present in biologically important regions of DNA that greatly required by cancer cell to proliferate untimely such as telomere and regulatory regions of oncogenes such as MYC. Thanks to the abundance of detailed information available regarding their potential biological activities, G-quadruplexes are viewed as emerging therapeutic targets in oncology [10-14].

Table 1. Interaction patterns between drug/small molecules and double stranded DNA.

\begin{tabular}{|c|c|c|c|c|}
\hline \multirow{4}{*}{ Drug } & \multicolumn{4}{|c|}{ Mode of Binding } \\
\hline & \multirow{3}{*}{$\begin{array}{c}\text { Covalent } \\
\text { Alkylating agents (irreversible } \\
\text { and leads to complete inhibition } \\
\text { of DNA processes and } \\
\text { subsequent cell death) }\end{array}$} & \multicolumn{3}{|c|}{ Non covalent } \\
\hline & & \multicolumn{2}{|c|}{ Groove binders } & \multirow[b]{2}{*}{ Intercalators } \\
\hline & & $\begin{array}{l}\text { Minor } \\
\text { groove } \\
\text { binders }\end{array}$ & $\begin{array}{r}\text { Major } \\
\text { groove } \\
\text { binders }\end{array}$ & \\
\hline $\begin{array}{c}\text { Cisplatin } \\
\text { (DNA crosslinker) }\end{array}$ & $\sqrt{ }$ & & & \\
\hline $\begin{array}{c}\text { Doxorubicin } \\
\text { (Stabilizes topoisomerase-II-DNA } \\
\text { cleavable) }\end{array}$ & $\sqrt{ }$ & & & \\
\hline $\begin{array}{c}\text { Etoposide } \\
\text { (Topoisomerase inhibitor) }\end{array}$ & $\sqrt{ }$ & & & \\
\hline Methotrexate & $\sqrt{ }$ & & & \\
\hline $\begin{array}{l}\text { (Antimetabolite, a folic acid antagonist) } \\
\text { (TFOs) Triplex-forming oligonucleotides } \\
\text { (oligomers that bind in the major groove } \\
\text { and form hydrogen bond with bases of the } \\
\text { purine strand) }\end{array}$ & & & $\sqrt{ }$ & \\
\hline
\end{tabular}


Table 1. Cont.

\begin{tabular}{|c|c|c|c|c|}
\hline \multirow{6}{*}{ Drug } & \multicolumn{4}{|c|}{ Mode of Binding } \\
\hline & \multirow{5}{*}{$\begin{array}{c}\text { Covalent } \\
\text { Alkylating agents (irreversible } \\
\text { and leads to complete inhibition } \\
\text { of DNA processes and } \\
\text { subsequent cell death) }\end{array}$} & \multicolumn{3}{|c|}{ Non covalent } \\
\hline & & Groov & inders & \\
\hline & & Minor & Major & Intercalator \\
\hline & & groove & groove & $\mathbf{s}$ \\
\hline & & binders & binders & \\
\hline (PNAs) peptide nucleic acids & & & $\sqrt{ }$ & \\
\hline \multicolumn{5}{|l|}{ (with peptide-like backbone that invade the } \\
\hline \multirow{2}{*}{\multicolumn{5}{|c|}{$\begin{array}{l}\text { helix to form a triplex which results in the } \\
\text { displacement of noncomplementary }\end{array}$}} \\
\hline & & & & \\
\hline \\
\hline (Daunomycin) combilexins & & & & $\sqrt{ }$ \\
\hline Quinacrine & & & & $\sqrt{ }$ \\
\hline Ethidium bromide & & & & $\sqrt{ }$ \\
\hline Netropsin & & $\sqrt{ }$ & & \\
\hline Distamycin & & $\sqrt{ }$ & & \\
\hline DAPI & & $\sqrt{ }$ & & \\
\hline
\end{tabular}

\section{G-Quadruplexes}

Guanine (G) -rich DNA sequences are susceptible to form in vitro G-quadruplexes as a consequence of the propensity of guanines to associate with each other in a stable hydrogen-bonded arrangement, the G-quartet [21-23]. G-quartets are stabilized by a monovalent cation $\left(\mathrm{Na}^{+}\right.$or $\left.\mathrm{K}^{+}\right)$ localized in the centre of the structure. Both nuclear magnetic resonance and X-ray crystallographic structures of G-quadruplexes have been obtained at high resolution [24,25]. Variations in the molecularity, topology, strand orientation and glycosidic conformation of the G-quadruplex DNA provide a diverse array of structures [26]. A three-dimensional arrangement of three G-quartets can result in a variety of G-quadruplex structures. The four-stranded quadruplex structural types depend on the number and the orientation of the DNA strands. Indeed, intramolecular G-quadruplexes are comprised of one DNA strand whereas dimeric and tetrameric intermolecular quadruplex involve two and four DNA strands, respectively. G-quadruplex heterogeneity also depends on the orientation of the DNA strands (parallel or anti-parallel) and the guanine conformation (syn or anti) [24,27,28]. Despite a wealth of crystal and solution structures, it has proved difficult to define a comprehensive set of rules that specify the folding propensity of G-quadruplexes based on specific sequences, moreover it has been reported that the same sequence can adopt different G-quadruplex conformations [29].

There is extensive literature on proteins that have been identified to bind G-quadruplexes [30-32], including proteins that either facilitate or non-catalytically disrupt G-quadruplex formation, as well as helicases that catalytically unwind G-quadruplexes in an ATP-dependent manner and nucleases that cleave at G-quadruplex scaffolds [33]. Although G-quadruplex structures have only been observed in vitro, strong indirect evidence for their existence in vivo comes from the characterization of G-quadruplex DNA binding proteins, helicases, and nucleases. [26,34]. Moreover monoclonal antibodies have been used successfully to confirm their in vivo, existence [35] however, controversial reports exist [36,37]. 
Bioinformatics and molecular sequence analysis indicates that G-quadruplexes are over-represented in specific regions of the genome with key biological contexts. This includes DNA telomere ends and promoter regions (translation start sites) of several important oncogenes $[21,33,38,39]$. It has been shown that the formation of quadruplexes inhibits the telomere extension by the telomerase enzyme, which is up-regulated in cancer cells, as well as negatively regulating oncogene's transcription [40,41] Because of its biological significance and antitumor potential, the G-quadruplex has attracted intense interest as an important target for drug design and development and there is a huge interest in design and development of small molecules to target these structures. A large number of so-called G-quadruplex ligands, displaying varying degrees of affinity and more importantly selectivity, have been reported $[42,43]$.

RNA structures in the untranslated regions (UTRs) of mRNAs influence post-transcriptional regulation of gene expression. There is now a growing body of evidence that has established a link between deregulation of translational control and disruption of normal cell behavior in human diseases, especially cancers. While much of the research has been focused on DNA G-quadruplexes, there has recently been a rapid emergence of interest in RNA G-quadruplexes, particularly in the 5'-UTRs of mRNAs. The recent in vitro demonstrations that small molecule G-quadruplex binding ligands can selectively target RNA G-quadruplexes open up a new and attractive avenue in RNA-directed drug design. Clearly, part of the challenge is to better understand the mechanistic effects and selectivity in vivo environment, however, it is clear that the RNA G-quadruplex motif represents a structurally attractive scaffold for small molecule targeting and given the promising early insights into their functional effects, this represents an attractive and fertile area for future research [10,33].

\section{G-Quadruplexes as a Potential Cancer Therapeutic Targets}

\subsection{Telomere Structure and Function}

The concept of targeting G-quadreplexes as a therapeutic strategy was first developed for telomeric DNA and telomerase inhibition. Telomeres are specialized DNA-protein complexes that cap the ends of linear chromosomes and provide protection against gene erosion at cell divisions, chromosomal nonhomologous end-joinings and nuclease attacks [44-46]. Telomere DNA consists of repetitive TTAGGG double-stranded tracks that span $\sim 10-15 \mathrm{~Kb}$ in length in humans and terminate with around 200-nt of a G-rich single-stranded overhang beyond the double-stranded region [47,48]. The single stranded DNA folds back and anneals with the double-stranded region to form a large telomeric loop, known as the T-loop [49]. As a consequence, a portion of the strand along the length of the overhang-invasion is displaced, forming a single-strand DNA region called a D-loop [50]. A group of telomere-associated proteins which help to stabilize the T-loop secondary structure are collectively called shelterins. These shelterin proteins comprise the telomere repeat factor 1 and factor 2 complexes (TRF1 and TRF2) that bind to double-stranded telomeric DNA and the protection of telomeres 1 protein (POT1) that binds the single-stranded 3` G-rich overhang. Three other interconnecting proteins (TIN2, TPP1, and RAP1) protect the telomere integrity by assisting in the T- and D-loop formation [51,52]. Telomere DNA in human cells shortens during each round of chromosome replication due to the end-replication problem $[53,54]$. In more than $85 \%$ of cancer cells, the telomere shortening is compensated by the telomerase enzyme that is especially up-regulated in cancer but not in somatic cells. 
Telomerase is a cellular ribonucleoprotein enzyme that stabilizes telomere length by adding TTAGGG repeats to the telomeric ends of the chromosomes. Human telomerase is composed of two main components, human telomerase RNA (hTR) and telomerase reverse transcriptase TERT [55-58]. This enzyme utilizes its own RNA as a template to synthesize telomeric DNA. Together with telomere-binding proteins, telomerase confers stability on the chromosomes and counteracts the telomere-dependent pathways of cell mortality. Telomerase activity changes through life, going from a peak of activity during the first trimester in utero, where virtually all the tissues have active telomerase [59], to undetectable levels after birth in most somatic tissues with the exception of highly proliferative cells such as germ cells and stem cell compartments [60]. Beside telomerase, in some tumors, telomeres are maintained by an alternative lengthening of telomere (ALT) mechanism [61-63]. In this process telomeres are usually longer and more heterogeneous than in telomerase-positive cells. However, the exact mechanisms involved in telomere elongation are poorly understood.

\subsection{Biological Significance of Telomeres and Telomerase during Development}

Highly proliferative cell types such as embryonic cells require active and controlled telomere maintenance strategies in order to protect the integrity of their genomes effectively. Telomere length was found to be regulated during human and animal embryogenesis by a telomerase-dependent mechanism [64]. In germ line cells, human telomeres are balanced between shortening processes with each cell division and elongation by telomerase, but once the cell is terminally differentiated or mature, the equilibrium is shifted to gradual telomere shortening by repression of the telomerase enzyme [65-71]. Embryonic stem cells that are capable of self-renewal and differentiate to any cell type in the body, maintain high levels of telomerase activity and TERT expression [72-75]. In 20 week old human foetus after the embryonic period and most of the organogenesis is accomplished, telomerase is rapidly down-regulated and expressed only at lower levels in tissue-specific stem cells [76,77].

\subsection{Telomeres and Telomerase Activity during Tumor Development}

Despite the impressive advances that have been made in cell and molecular biology, how embryonal tumor cells are actually initiated and progress is still widely debated. The concept that the incidence of cancer rises exponentially in the final decades of life due to the sequential accumulation of the somatic mutations does not really fit the onset of pediatric cancers that develop and manifest early in childhood. Identification of the cells that mediate tumor initiation in childhood cancer and finding out the information that is necessary for the cell to transform into a neoplastic cell should provide an important baseline for better treatment of childhood embryonic cancers [78,79].

Different hypotheses have been postulated in the literature: one assumes that a somatic differentiated cell can dedifferentiate or reprogramme to regain properties associated with cancer cells whereas others claim that a stem cell is needed to initiate the carcinogenic process [80]. The first model scenario depends on the hypothesis that rapid proliferation of the telomerase negative dedifferentiated somatic cells can lead to shortened telomeres that may promote chromosomal and genomic instability which then primes the cell to become cancerous. In a later stage telomerase is then activated and stabilizes the previously shortened telomeres, thereby prolonging the lifespan of cancer cells. This hypothesis has been supported experimentally by the observation that almost all malignant 
cancers have telomerase activity, despite their shortened telomeres [65,81-84]. Indirect support for this view comes from the observations that benign or pre-cancerous lesions are telomerase silent [81]. Moreover high telomerase levels are found to correlate with worse clinical outcomes [85]. This model implies that telomerase activation in cancer is an induced or aberrant function in otherwise enzyme-deficient somatic cells destined for senescence [86]. The second interesting hypothesis is that the tumor cells are telomerase positive not because of TERT expression under a selective pressure, but because they are derived from the oncogenic transformation of a stem cell or a pluripotent early precursor cell which has retained its telomerase activity [76,86,87]. This concept has been proposed for several tumors [88] and supported by a number of reports demonstrating the presence of cancer stem cells in different adult cancers $[89,90]$. In pediatric malignancies the cancer stem cell hypothesis was recently described in studies performed on leukaemia, where it was shown that a single cell with stem cell markers had the capability to induce the disease in mice [91]. More recently, cancer stem cells have also been isolated from solid embryonal tumors such as MB, NB, Ewing's sarcoma, RMS and HB [92-97]. The second model scenario highlights the importance of telomere length maintenance in stem cell populations to facilitate cell division that is required for tissue homeostasis. However there has to be a balance between maintaining regenerative potential, on one hand and tumor suppression on the other. One mechanism that may contribute to adjust this balance is the length of telomeres per se, whereby stem cells may need to maintain telomeres at a length that provides sufficient replicative capacity for tissue homeostasis, versus the requirement to minimize telomere length and replicative capacity as a tumor suppressive mechanism [98]. There is a suggestion that during the tumorigenesis process telomere erosion may have evolved to a level where telomeric repeat sequences are too short to provide a functional substrate for telomerase enzyme activity [99]. In this scenario, as telomeres shorten with each cell cycle the "sticky" ends of chromosomes become prone to fusions [100] leading to subsequent chromosomal instability [100-103] and offering a mechanism for a continuous rearrangement of chromosome structure that might contribute to oncogene amplification and tumor suppressor gene deletion [104,105]. In fact, concurrent telomere shortening and genomic instability have been observed in the majority of embryonic tumors including: Wilms' tumor [106,107], MB [108,109], NB [110,111] and rhabdomyosarcoma [112,113]. The view represented by the stem cell origin of embryonal tumors implies that the genetic alterations which lead to cancer accumulate in embryonal stem cells rather than mature cells. However, an alternative opinion held is that it is important to separate tumor-initiation and tumor-propagation; this may not involve the same cell type as the tumor-propagating cell may be a much differentiated progeny of the tumor-initiating cell. Hence improved therapeutic efficacy may be achieved by targeting both cell types which drives malignant progression as well as thesewhich initiates and maintains the stem cell pool of the tumor [114].

Ultimately whether embryonal cancer cells reactivate the telomerase or up-regulated telomerase activity, the telomere maintenance process seems to play a crucial role in the initiation and progression of cancer. Since telomerase is not expressed in most normal human cells, this has led to the development of targeted telomerase cancer therapeutic approaches which are at present in advanced clinical trials. 


\subsection{Significance of Telomere Biology in Embryonal Tumors of the Nervous System}

The erratic clinical behaviour of pediatric embryonal tumors suggests a variable proliferative potential, thus making them attractive candidates for the study of telomere maintenance biology as a possible prognostic marker and/or therapeutic target. Elevated telomerase activity and telomere shortening could be signs of the excessive cell divisions experienced by cancer cells and could reflect the stage of malignancy and disease prognosis [115]. Down-regulation of telomerase activity has been shown to induce cancer cell growth arrest and differentiation, which might predict a close correlation between telomerase activity levels and clinical outcome, while tumors with sustained telomerase activity might therefore become choice targets for telomerase directed therapy [116-119]. Telomere maintenance biology have been studied in the majority of embryonic tumors including Wilms' tumor [106,107,120], Ewing's sarcoma [121-123], hepatoblastoma [8,124], MB [108,109,125,126], NB [127,128] and rhabdomyosarcoma $[112,129]$. We will focus below on pediatric malignancies of the central and peripheral nervous system MB and NB.

\subsubsection{Neuroblastoma}

NB is the most common extra-cranial solid tumour of childhood and accounts for at least $15 \%$ of cancer-related deaths in children [4]. NB is derived from primitive cells of the sympathetic nervous system and so it can be found anywhere along the paravertebral sympathetic chain or in the adrenal gland [130,131]. The clinical outcome of NB can range from complete regression (mainly in infants) to rapid tumor progression and metastasis with poor prognosis [132]. Identification of the most common genomic alterations associated with the disease has allowed the classification of NB into low-, intermediate- and high-risk groups [4,133]. Unfavorable tumors are characterized by deletions of $1 \mathrm{p}$ or 11q, unbalanced gain of 17q and/or amplification of MYCN [134].

Studies by several independent laboratories aimed at understanding the dynamics of telomere-telomerase interaction in NB suggested that telomerase activity is a robust prognostic indicators [127,128,135-137] and can discriminate between prognostically different subsets of NB $[85,138,139]$. Hiyama et al. reported that telomerase is expressed in $94 \%$ of NB patients' samples, but not in benign ganglioneuromas or adjacent adrenal tissues: $75 \%$ of tumors with high telomerase activity had a poor prognosis, $97 \%$ of tumors with low telomerase activity had a good prognosis and $100 \%$ of tumors with no detectable telomerase activity regressed [85,135]. Similarly, in a study of a large cohort, telomerase activity was detected in 39/133 (29\%) tumors including 25/41 (61\%) Stage 4, 8/23 (35\%) Stage 3, 0/13 (0\%) Stage 2, 2/32 (6\%) Stage 1 and 4/24 (17\%) Stage 4S NB. In this study telomerase activity emerged as an independent predictor of clinical outcome with greater prognostic impact than the MYCN status and even the clinical stage [140]. The level of RNA subunit of telomerase (hTR) has also been found to be associated with the clinical stage of NB at diagnosis [141]. High expression of hTR was associated with advanced disease and with unfavorable prognosis, while most patients with weak or absent hTR expression were found to belong to early tumor stages $[138,141]$. NB patients classified as $4 \mathrm{~S}$ stage, known to have a good prognosis and usually demonstrating spontaneous regression, were found to exhibit short telomeres and to express no detectable telomerase activity at diagnosis, in contrast to patients with progressive disease [135,136]. Hence it has been 
hypothesized that the aggressive tumors express telomerase (and therefore have stabilized telomeres), whereas the regressing tumors may have absent or low levels of telomerase activity (allowing telomeres to continue shortening). In a retrospective study on $124 \mathrm{NB}, \mathrm{Krams}$ et al. have shown that both spliced and full-length hTERT transcripts were significantly associated with $M Y C N$ amplification while full-length hTERT transcripts were highly predictive of poor outcome [142]. In a recent work we examined telomestatin, a G-quadruplex interactive agent, for its ability to inhibit telomere maintenance of neuroblastoma cells. In this study treatment with telomestatin resulted in telomerase inhibition, telomere shortening, cell growth suppression and induction of apoptosis through disruption of telomere maintenance [143].

\subsubsection{Medulloblastoma}

MB is a malignant, invasive tumor of the cerebellum and the most common primary pediatric malignancy of the central nervous system. Classified as a primitive neural ectoderm tumor that is thought to arise from granule cell precursors. The standard of care consists of surgery, chemotherapy and age-dependent radiation therapy. Despite aggressive therapy approximately $30 \%$ of MB patients remain incurable. Moreover, for long-term survivors, the treatment related sequelae are often debilitating. Side effects include cerebellar mutism, sterility, neurocognitive deficits and a substantial risk of developing secondary cancers. Hence more effective and targeted therapies are certainly needed [144].

In contrast to $\mathrm{NB}$, data on the role of telomere/telomerase biology in $\mathrm{MB}$ are scarce and examination of the few reports that do exist yields conflicting results. Studies have shown that large increases in chromosomal material in the 5p15 region, where the TERT gene is located, are detectable in MB, suggesting that the TERT gene could be amplified in CNS embryonal tumors $[83,145,146]$. Fan et al. used differential PCR and real-time RT-PCR to determine the relationship between TERT gene copy number, TERT mRNA expression and clinical outcome in CNS embryonal tumors including MB [147]. The group found that the TERT gene was amplified in $42 \%$ of 36 primary MB samples examined. The TERT amplification was found to correlate with the increased expression of TERT mRNA in almost all the tumors, while MB patients with increased TERT expression in their tumors showed a trend towards worse clinical outcomes. The authors suggested that changes may have happened at the TERT locus during the evolution of $\mathrm{MB}$, indicating a possible role for telomerase in the pathogenesis of MB [147]. Other groups, including our laboratory [148-151], detected telomerase enzyme activity in cultured MB cells in vitro. Our lab investigated the mRNA expression level of TERT in 50 primary MB samples and compared it with seven normal brain samples. $76 \%$ of the primary MB samples had upregulated TERT mRNA expression [148-151]. While a positive correlation between TERT mRNA expression and telomerase activity was detected in MB cell lines, no correlation was found between telomerase activity and telomere length. Treatment of MB cell lines with the telomerase inhibitor epigallocatechin gallate displayed strong dose dependent proliferation inhibitory effects against telomere repeat amplification protocol (TRAP)-positive MB cell lines [148-151]. Our results suggest that inhibition of telomerase function could represent a novel experimental therapeutic strategy in childhood MB. In contrast, however, by screening a heterogeneous group of brain tumors for telomerase activity, MB was found to be the only telomerase negative in the series of brain tumors tested $[152,153]$. Hence these results may provide a stimulus for future research aimed at uncovering the real role, if any, that telomere maintenance might play in the pathogenesis of MB. 


\subsection{Significance of the myc Oncogene Family in Embryonal Tumors of the Nervous System}

\subsubsection{MYC in neuroblastoma}

The myc family of nuclear oncogenes contains three well-characterized members, c-myc (MYC), MYCN, and L-myc. These genes encode related but distinct nuclear proteins that can contribute to tumorigenic conversion both in vitro and in vivo. However, each gene displays a unique activation pattern that partially reflects the distinctive expression of each gene during normal tissue as well as during tumor development [153]. MYCN amplification in NB has been established as a predictive marker for poor outcome which is associated with a survival rate of $15 \%-35 \%[154,155]$. MYCN is vital for proliferation, migration and stem cell homeostasis while decreased levels are associated with terminal neuronal differentiation. In addition, high risk tumors without $M Y C N$ amplification frequently express elevated levels of MYC [156]. Recent microarray data from NB patients showed that genes in the MYC pathway significantly correlated to poor survival independent of MYCN amplification [157]. By using these expression profiles, the authors identified patients with adverse outcomes that initially were diagnosed as low or intermediate risk [157], emphasizing the importance of MYC signaling in NB biology. Retinoic acid has been shown to downregulate MYCN expression and to induce neuronal differentiation of NB cells in vitro. Together, these findings indicate that MYC signaling is important in maintaining an undifferentiated phenotype and that inhibition of MYC could contribute to less aggressive tumors and maybe even lead to new and improved therapies for high-risk patients (reviewed in [158]). Several labs have explored the effect of down regulating MYCN expression in $M Y C N$-amplified NB cell lines using antisense or RNA interference approaches in vitro and in vivo [159-165]. Collectively these studies demonstrated that decreased MYCN expression in NB cells leads to growth arrest, apoptosis and/or differentiation. The results of these studies indicate that MYCN could be a promising therapeutic target for NB. However the use of antisense or RNA interference as a therapeutic strategy in the clinic has been limited due to insufficient delivery and specificity problems. It is therefore of particular relevance to find an alternative approach to achieve a better targeting of MYCN in NB in view of discovering new therapeutic targets.

\subsection{2. $M Y C$ in medulloblastoma}

MYC has emerged as an important modulator and prognostic indicator of MB malignancy [166-168]. Amplification of $M Y C$ has been reported in 5\%-15\% of MB overall, while amplification of $M Y C N$ has been found in $\sim 10 \%$ of cases [169-171]. MYC expression and amplification have been associated with poor patient prognosis [166,172] and with the prognostically dismal large cell/anaplastic MB subtype [167,171,173]. MYCN was shown to be upregulated by Hh signaling and to mediate the effects of Hh activation on the proliferation of cerebellar granule precursors [174,175]. MYC was found to cooperate with $\mathrm{Hh}$ by enhancing tumorigenicity of nestin-expressing neural progenitors that are present in the cerebellum at birth and that can act as the cells-of-origin for MB [176] and reviewed in [177]. Based on the above, MYC appears to play a central role in deviating many of the signaling pathways to specific effectors involved in MB pathogenesis, therefore it represents an attractive target for the therapy of these neoplasms. However, contrary to the substantial amount of preclinical studies in NB, the investigation of MYC-specific therapeutic approaches in MB is still in its infancy. Unfortunately, 
clinically useful inhibitors of MYC are not available to date and efforts to develop such drugs would certainly be needed. Our lab as well as others used an antisense approach to silence MYC [178], which led to an inhibition of cell proliferation and to an arrest of the cell cycle in the $\mathrm{S}$ phase. The synthetic quassinoid derivative NBT-272, is currently under investigation in our group, on the basis of previous findings obtained in a panel of MB-derived cell lines [179]. In this report, NBT-272 was able to reduce cell proliferation and to block cell cycle progression [180]. We evaluated recently the effects of G-quadruplex targeting compound S2T1-6OTD on a representative panel of human MB and atypical teratoid/rhabdoid AT/RT childhood brain cancer cell lines. S2T1-6OTD is a novel telomestatin derivative that is synthesized to target G-quadruplex-forming DNA sequences in the MYC promoter. We showed that treatment with S2T1-6OTD reduced the mRNA and protein expressions of MYC and hTERT, which is transcriptionally regulated by MYC, and decreased the activities of both genes. In remarkable contrast to control cells, short-term (72-hour) treatment with S2T1-6OTD resulted in a dose and time-dependent antiproliferative effect in all MB and AT/RT brain tumor cell lines tested with IC50 at micromolar level. Under conditions where inhibition of both proliferation and MYC activity was observed, S2T1-6OTD treatment decreased protein expression of the cell cycle activator cyclin-dependent kinase 2 and induced cell cycle arrest. Long-term treatment (5 weeks) with nontoxic concentrations of S2T1-6OTD resulted in a time-dependent (mainly MYC-dependent) telomere shortening. However, telomestatin is known to bind to the G-quadruplex in the TERT promoter, and this may mediate at least part of its effect on TERT [180]. Telomere shortening was accompanied by cell growth arrest and followed by cell senescence and induction of apoptosis in all five cell lines investigated [181,182]. Ref.181 missing In vivo animal testing will now be needed to determine whether S2T1-6OTD may represent a novel therapeutic strategy for childhood brain tumors.

\section{Targeting G-Quadruplex as a Novel Anticancer Strategy}

\subsection{Targeting Telomere Maintenance}

The interest in telomere maintenance mechanisms in a cancer therapeutics context came to light following the observations that immortality of human cancer cells is intimately related to the maintenance of the ends of human chromosomes [183,184]; in addition over $85 \%$ of human tumor samples including cancer stem cells are telomerase-positive [56-58]. In fact no other tumor-associated gene is as widely expressed in cancer. This concept was coupled with the remarkable reports by Hahn and colleagues' showing that cloning a mutant TERT gene into a cancer cell causes the cell to lose the ability to form tumors in mice, leads to shortening of telomeres and forces the cell into replicative senescence $[183,185]$. Soon afterwards cumulative reports continued to demonstrate and provide evidence for the genetic validation of telomere maintenance as an anticancer target [186-189].

Telomere DNA in human cells shortens during each round of chromosome replication due to the end-replication problem $[53,54]$. In most cancer cells the telomere shortening is compensated by the telomerase enzyme. Optimal telomerase activity requires the unfolding of the single-stranded 3 ' ends of telomeric DNA substrate that gives access to the telomerase RNA to allow priming and elongation of the telomere length. To this end, telomerase hybridize to the single-stranded 3 ' ends of telomeric DNA and add new nucleotides in order to maintain telomere length and accordingly uphold the 
proliferative ability of the cancer cells $[81,190]$. This link to cancer biology propelled the development of new strategies to limit cancer cell growth using the interference with telomere maintenance via telomerase inhibition [191,192]. One recent approach to telomerase inhibition involves the sequestration of the single-stranded 3' ends of telomeric DNA into higher-order quadruplex structures [190,193]. A desired ligand would recognize a G-quadruplex structure formed by human telomeric sequences with high affinity and specificity. Many of the reported G-quadruplex ligands contain planar aromatic rings, which can interact with human telomeric G-quadruplex by stacking on the terminal G-tetrads (Figure 1).

Figure 1. Interaction modes between G-Quadruplex structures and ligands.

A

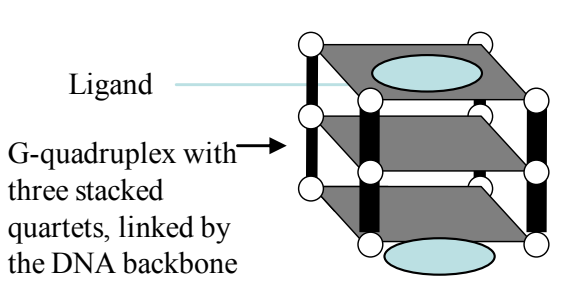

B

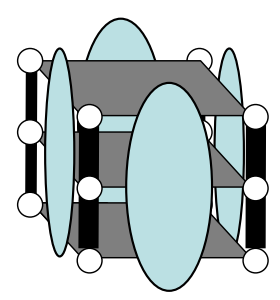

C

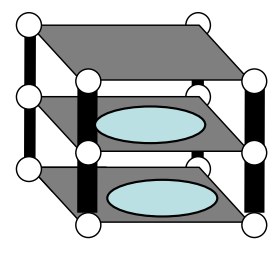

Small organic molecules have been proposed to interact noncovalently with G-quadruplex through (A) tetrad end stacking, (B) groove binding and (C) intercalation between the two G-tetrads.

In addition to the end-stacking binding mode of the aromatic rings, some ligands also contain other moieties that can recognize loops by stacking with loop bases or forming intermolecular hydrogen bonds or recognize the backbone with electrostatic interactions. The grooves in G-quadruplexes can also be recognized through hydrogen bonds or hydrophobic interactions Alternatively the G-rich human telomeric DNA strand can be trapped in a G-quadruplex structure with a linear guanine-containing molecule based on a different backbone, such as PNA [194].

The formation of a quadruplex-ligand complex at telomere ends appears to be equivalent to the exposure of damaged DNA, since it elicits a rapid DNA damage response that is lethal to the affected cancer cells [195]. Several selective drug-like small molecule ligands were developed to target the quadruplex forming 3'-telomeric end DNA sequences and a growing number of different cancer research groups including our lab, started to use some of these compounds to test cancer growth inhibitory effects [196-198]. Most of the small molecules discovered showed a strong ability to stabilize these motifs and were successful in telomerase inhibition, thereby identifying the human telomeric DNA G-quadruplexes as attractive potential targets for cancer therapeutic intervention $[8,187]$. However lack of selectivity towards telomere quadruplex motifs has been also reported [187].

Interestingly some G-quadruplex-targeting compounds have been shown to disrupt telomere capping and induce rapid apoptosis in cancer cells, even in the absence of telomere shortening [186,187]. This finding cannot be explained solely by telomerase inhibition. Rather, it indicates to a certain extent that the direct target of these ligands is telomere dysfunction rather than telomerase inhibition. Furthermore, G-quadruplex-targeting compounds have also been shown to inhibit the alternative lengthening of telomeres (ALT) pathway, which maintains telomere stability in a telomerase-independent manner in around $15 \%$ of cancer cells whereby telomerase is not activated [199]. 


\subsection{Targeting G-quadruplexes in Oncogene Promoters}

In addition to their existence in telomere sequence, bioinformatic analyses combined with biophysical and structural investigations have highlighted the relative abundance of putative G-quadruplex forming sequences in promoter regions of oncogenes close to their transcription start sites [200,201]. Oncogenes with putative G-quadruplex forming sequences in their promoters includes: c-kit [202,203]; k-ras [204]; hTERT [205,206]; Bcl-2 [207]; VEGF [208]; HIF-1[209]; c-myb [210]; c-myc [211-213] PDGF-A [214] pRb [215] reviewed in [216]. Interestingly it has been shown that the potential for quadruplex formation is higher within oncogenes' promoters compared to tumor suppressor genes [199,217]. Considerable focus has been placed on the MYC gene promoter making it the most extensively studied system for the G-quadruplex formation [112,199,211,218,219] important regulator of a wide array of cellular processes necessary for normal cell growth and differentiation and its dysregulation is one of the hallmarks of many cancers [220]. Hence studying MYC transcriptional activation is critical for understanding developmental and cancer biology, as well as for the development of new anticancer drugs.

Following the successful demonstration that the activity of telomerase can be inhibited by small molecule-induced stabilization of telomeric G-quadruplex, Hurley and co-workers reported the seminal discovery of a potential $\mathrm{G}$ quadruplex structure in the nuclease hypersensitive element III1 (NHEIII) of the promoter region of the MYC oncogene that controls up to $80 \%-90 \%$ of the transcriptional activity of this gene $[221,222]$. The authors further demonstrated that the transcriptional repression of MYC can be achieved by induction of putative G-quadruplex formation by a small molecule [223]. Evidently, MYC transcription was inhibited by the putative formation of the G-quadruplex structure in the promoter region, thus suppressing oncogenic expression [212]. Additional support for this idea came from cellular experiments in both our and other labs, whereby transcription of MYC and hTERT was inhibited upon addition of the G-quadruplex-interactive compound TMPyP4 [36] or the telomestatin derivative S2T1-6OTD [181,182]. Unlike telomeric G-quadruplexes, which can be formed from the single-stranded DNA template at the 3' end of human telomeres, G-quadruplexes in gene promoter regions are constrained by the duplex nature of genomic DNA. It has been found that each of the single-stranded elements, in gene promoter double stranded DNA, could be a precursor to the formation of secondary DNA structures (G-quadruplexes and i-motifs on the G-rich and C-rich strands, respectively) reviewed in [224]. Each of the single strands have the ability to form isomorphic protruding structures, which are in equilibrium with the double-stranded B-DNA form of that region [181,222]. The protruding G-quadruplex structure and the I-motif formed on the opposite strand keep the two DNA strands separated and prevent the formation of the basal transcriptional complex. When this promoter region is in B-DNA form the transcription can be initiated [225]. Compounds that bind to and stabilize the G-quadruplex conformation have been shown to reduce MYC expression and are antitumorigenic, supporting the proposed hypothesis [182,226,227].

\section{G-Quadruplex-Interactive Small-Molecules}

The therapeutic potential of G-quadruplexes has resulted in a rapidly increasing number of studies in which small-molecule ligands have been used to act as G-quadruplex stabilizers. Several hundreds 
of small molecules that interact with G-quadruplexes have now been described in the literature [226-230], however cellular and in vivo data are only available for a small number of these compounds [193]. These compounds may be of natural origin such as cryptolepine, berberine and telomestatin or synthetic ones such as BSU1051, RHPS4, TMPyP4, pyridine or phenanthroline dicarboxamides, triazines, PIPER or bi- and trisubstituted acridines such as BRACO19. Other potential G-quadruplextargeting drugs including quindoline derivatives and 307A has shown various levels of selectivity and potency in binding to G-quadruplexes (Table 2). Many such agents are currently in various stages of preclinical testing and some of them will likely enter the clinic in the near future [199].

Table 2. Small molecules showed antitumor activity in both adults and pediatric cancers. Reviewed in [229,230].

\begin{tabular}{|c|c|c|c|}
\hline Ligand & Tumor model tested & Antitumor activity & Reference \\
\hline Telomestatin & $\begin{array}{l}\text { Neuroblastoma, myeloma, } \\
\text { acute leukemia and glioma } \\
\text { stem cells }\end{array}$ & $\begin{array}{l}\text { Telomerase inhibition, } \\
\text { telomere length reduction } \\
\text { - Inhibition of proto-oncogene } \\
\text { c-Myb expression } \\
\text { - Antiprolifrative activity, } \\
\text { apoptosis induction and } \\
\text { increased chemosensitivity } \\
\text { - Impairs cancer stem cell } \\
\text { survival and growth }\end{array}$ & [231-240] \\
\hline $\begin{array}{c}\text { S2T1-6OTD } \\
\text { (telomestatin } \\
\text { synthetic Derivative) }\end{array}$ & $\begin{array}{l}\text { Paediatric brain cancer } \\
\text { (Medulloblastoma and } \\
\text { atypical teratoid/rhabdoid) }\end{array}$ & $\begin{array}{l}\text { - MYC and hTERT inhibition } \\
\text { - Telomere shortening } \\
\text { - Cell cycle arrest and tumor } \\
\text { cell's growth inhibition }\end{array}$ & {$[182]$} \\
\hline $\begin{array}{l}\text { HXDV } \\
\text { (telomestatin } \\
\text { synthetic } \\
\text { Derivative) }\end{array}$ & $\begin{array}{c}\text { A panel of normal/cancer } \\
\text { telomerase- and ALT-positive } \\
\text { cell lines }\end{array}$ & $\begin{array}{l}\text { - Inhibition of cell growth } \\
\text { independently of telomerase } \\
\text { activity } \\
\text { - M-phase cell cycle arrest } \\
\text { - Mitotic defects } \\
\text { - Induction of apoptosis }\end{array}$ & [241] \\
\hline $\begin{array}{l}\text { TMPyP4 } \\
\text { (Cationic porphyrin) }\end{array}$ & $\begin{array}{c}\text { Myeloma, cervical, } \\
\text { pancreatic, breast, colon, } \\
\text { prostate cancer and } \\
\text { osteosarcoma, neuroblastoma } \\
\text { and retinoblastoma }\end{array}$ & $\begin{array}{l}\text { - MYC and hTERT inhibition } \\
\text { - Blockage of telomerase } \\
\text { elongation } \\
\text { - Antiproliferative activity }\end{array}$ & {$[242-246]$} \\
\hline $\begin{array}{l}\text { SYUIQ-5 and other } \\
\text { quindoline } \\
\text { derivatives }\end{array}$ & $\begin{array}{c}\text { Leukemia, Burkitt's } \\
\text { lymphoma, human epithelial } \\
\text { carcinoma, nasopharyngeal } \\
\text { carcinoma }\end{array}$ & $\begin{array}{l}\text { - } \text { MYC and hTERT inhibition } \\
\text { - Antiproleferative activity } \\
\text { cellular senescence; apoptosis } \\
\text { induction }\end{array}$ & {$[2,41,58,226,247,248]$} \\
\hline $\begin{array}{c}\text { Tetrasubstituted } \\
\text { napthalene diimides } \\
\text { ligands }\end{array}$ & $\begin{array}{l}\text { Brest, prostate cancer, and } \\
\text { lung adenocarcinoma }\end{array}$ & $\begin{array}{l}\text { - Inhibition of telomerase, } \\
\text { activity }\end{array}$ & [249] \\
\hline
\end{tabular}


Table 2. Cont.

\begin{tabular}{|c|c|c|c|}
\hline $\begin{array}{l}\text { Ligand } \\
\text { Triazine derivatives }\end{array}$ & $\begin{array}{c}\text { Tumor model tested } \\
\text { Melanoma, mouth, lung, } \\
\text { colon cancer as well as, lung } \\
\text { adenocarcinoma }\end{array}$ & $\begin{array}{l}\text { Antitumor activity } \\
\text { - Impairs the splicing machinery } \\
\text { of hTERT by stabilizing } \\
\text { quadruplexes located in the } \\
\text { hTERT intron } 6 \\
\text { - Telomere shortening } \\
\text { - Antitelomerase activity, } \\
\text { senescence and cancer cell } \\
\text { growth arrest }\end{array}$ & $\begin{array}{c}\text { Reference } \\
{[250-254]}\end{array}$ \\
\hline $\begin{array}{c}\text { Trisubstituted } \\
\text { acridine (AS1410) }\end{array}$ & Breast and lung cancer & $\begin{array}{l}\text { - Synergistic activity in } \\
\text { combination with cisplatin }\end{array}$ & [255] \\
\hline $\begin{array}{l}\text { BRACO-19 } \\
\text { 3,6,9-trisubstituted } \\
\text { acridine }\end{array}$ & $\begin{array}{l}\text { Breast and prostate cancer, } \\
\text { uterus and vulval carcinoma }\end{array}$ & $\begin{array}{l}\text { - Decreases hTERT expression } \\
\text { - Induction of cellular } \\
\text { senescence; cessation of cell } \\
\text { growth }\end{array}$ & {$[252,253,256-260]$} \\
\hline $\begin{array}{c}\text { Pentacyclic } \\
\text { acridines (RHPS4) }\end{array}$ & $\begin{array}{l}\text { Melanoma, breast and vulval } \\
\text { cancer }\end{array}$ & $\begin{array}{l}\text { - Telomerase inhibition } \\
\text { - Telomere capping disruption } \\
\text { - Apoptosis via PARP-1 } \\
\text { activation } \\
\text { - Cell cycle perturbations and } \\
\text { decrease in cancer cell growth } \\
\text { - Increased sensitivity to } \\
\text { chemotherapy }\end{array}$ & {$[253,259,261-266]$} \\
\hline $\begin{array}{l}\text { 4,5-di-substituted } \\
\text { acridone }\end{array}$ & Breast and lung cancer & $\begin{array}{l}\text { - Inhibition of telomerase activity } \\
\text { - Telomere length shorting } \\
\text { - Senescence induction, cancer } \\
\text { cell growth inhibition }\end{array}$ & [267] \\
\hline $\begin{array}{l}\text { Anthracene } \\
\text { derivatives }\end{array}$ & $\begin{array}{l}\text { Melanoma, colon cancer and } \\
\text { osteogenic sarcoma }\end{array}$ & $\begin{array}{l}\text { - Telomere dysfunction } \\
\text { - Senescence and cell growth } \\
\text { impairment }\end{array}$ & [268] \\
\hline $\begin{array}{c}\text { Amidoanthraquinone } \\
\text { derivatives }\end{array}$ & $\begin{array}{c}60 \text { different human cancer cell } \\
\text { lines }\end{array}$ & $\begin{array}{l}\text { - Telomerase inhibition } \\
\text { - High anti-proliferative activity }\end{array}$ & [269] \\
\hline Perylene derivatives & $\begin{array}{l}\text { Melanoma, colon and breast } \\
\text { carcinomas and osteosarcoma } \\
\text { and colorectal carcinoma cell }\end{array}$ & $\begin{array}{l}\text { Selectiv for telomeric } \\
\text { G-quadruplex with respect to } \\
\text { duplex genomic DNA. } \\
\text { - Telomerase inhibition. }\end{array}$ & {$[270,271]$} \\
\hline $\begin{array}{l}\text { Macrocyclic pyridyl } \\
\text { polyoxazoles }\end{array}$ & $\begin{array}{c}\text { Oral carcinoma and breast } \\
\text { cancer }\end{array}$ & $\begin{array}{l}\text { - Selective for G-quadruplex } \\
\text { DNA with no stabilization of } \\
\text { duplex DNA or RNA } \\
\text { - Cytotoxic to cancer cell line }\end{array}$ & {$[272,273]$} \\
\hline $\begin{array}{l}\text { Triethylene } \\
\text { tetramine (TETA) }\end{array}$ & $\begin{array}{l}\text { Brest cancer and human } \\
\text { epithelial carcinoma }\end{array}$ & $\begin{array}{l}\text { - Telomerase activity inhibition } \\
\text { - Induction of cellular senescence }\end{array}$ & {$[274,275]$} \\
\hline $\begin{array}{l}\text { Bisquinolinium } \\
\text { pyridine } \\
\text { dicarboxamide } \\
\text { compound }(360 \mathrm{~A})\end{array}$ & $\begin{array}{c}\text { Cervical cancer and colorectal } \\
\text { carcinoma }\end{array}$ & $\begin{array}{l}\text { - Telomere aberrations } \\
\text { - Impair mitotic cell progression } \\
\text { and lead to cell death. }\end{array}$ & {$[276,277]$} \\
\hline
\end{tabular}


Table 2. Cont.

\begin{tabular}{|c|c|c|c|}
\hline $\begin{array}{c}\text { Ligand } \\
\text { 307A } \\
\text { 2,6-pyridin- } \\
\text { dicarboxamide } \\
\text { derivative }\end{array}$ & $\begin{array}{l}\text { Tumor model tested } \\
\text { Glioma and osteosarcoma }\end{array}$ & $\begin{array}{l}\text { Antitumor activity } \\
\text { - } \quad \text { Equipotent against MYC and } \\
\text { telomeric G-quadruplex- } \\
\text { forming sequences } \\
\text { - } \quad \text { Inhibiting proliferation and } \\
\text { induce apoptosis }\end{array}$ & $\begin{array}{c}\text { Reference } \\
{[278]}\end{array}$ \\
\hline $\begin{array}{c}\text { Bisantrene } \\
\text { derivatives (An1,5) }\end{array}$ & $\begin{array}{l}\text { Melanoma and osteogenic } \\
\text { sarcoma }\end{array}$ & $\begin{array}{l}\text { - Inhibit telomerase activity } \\
\text { long-term cell growth } \\
\text { inhibition in both } \\
\text { telomerase- and ALT- } \\
\text { positive cancer cell lines } \\
\text { - Induction of senescence and } \\
\text { autophagy }\end{array}$ & [268] \\
\hline
\end{tabular}

Two of the most studied small molecules are telomestatin for telomeric and TMPyP4 for MYC quadruplexes. Telomestatin is one of the most potent and selective G-quadruplex binding small molecules known so far. Telomestatin is a natural product isolated from Streptomyces anulatus 3533-SV4 that acts by inhibiting the telomerase activity of cancer cells [232]. It induces the formation of baskettype G-quadruplex structures in the telomeric region, impairs telomere replication and inhibits growth of tumor cells [233]. There is compelling evidence that telomestatin as well as the synthetic BRACO19 and RHPS4 act not only by inhibiting the catalytic function of telomerase, but also by uncapping telomerase from the $3^{\prime}$ ends of telomeres, as reviewed in [234]. Evidence of antitumor activity in various xenograft models has been reported for telomestatin, adding to its widely displayed anticancer activity in human cancer cells including multiple myeloma, acute leukemia, NB, cells where it inhibited telomerase activity, reduced telomere length and caused apoptotic cell death [234-236] and also increased chemosensitivity in some of these malignancies. Recently telomestatin was found to impair glioma stem cell survival and growth through the disruption of telomeric G-quadruplex and inhibition of the proto-oncogene, c-Myb [237]. However no study of telomestatin has as yet progressed to clinical evaluation.

TMPyP4 (mesotetra (N-methyl-4-pyridyl) porphine) TMPyP4 is a G-quadruplex-targeting ligand that has been used in a large number of studies. TMPyP4 is known to bind strongly to DNA quadruplexes by stacking on the G-tetrads at the core of the quadruplex, resulting in telomerase inhibition [238]. In vitro and vivo data showed that, TMPyP4 displayed an antiproliferative effect on cancer cells [239] through its interaction with the G-quadruplex formed in the promoter region of MYC gene [223] that consequently downregulate MYC and its downstream targets [36]. However, a major hurdle in the development of TMPyP4 as a G-quadruplex target agent is its ability to bind to duplex DNA [279] and triplex DNA [280]. Thus, attempts have been made to generate second-generation cationic porphyrins with high selectivity for G-quadruplexes [281]. A more selective agent for the MYC G-quadruplex is the telomestatin derivative S2T1-6OTD, which has been shown to reduce the expression of MYC and TERT in childhood MB and in AT/RT tumor cells and has potent antiproliferative effects [181,182]. 


\section{G-Quadruplex-Targeting Drugs in Clinical Trials}

Quarfloxin (also known as CX-3543 or itarnafloxin), is a first-in-class G-quadruplex-interacting compound that has reached Phase II clinical trials for the treatment of neuroendocrine/carcinoid tumors. Quarfloxin is a fluoroquinolone-based antitumor agent derived from norfloxin via A-62176 and QQ58. The latter compound has a mixed mechanism of action as a topoisomerase II poison and a G-quadruplex interactive compound [224,279-282]. It was shown by the Hurley laboratory, the developer of this small molecule, that quarfloxin is highly selective for the G-quadruplex versus duplex or single-stranded DNA, and it is more selective for the MYC G-quadruplex versus other G-quadruplexes [282]. Quarfloxin disrupts the interaction between the nucleolin protein and a G-quadruplex DNA structure in the ribosomal DNA (rDNA) template, a critical interaction for rRNA biogenesis that is overexpressed in cancer cells. Disruption of this interaction may result in the inhibition of ribosome synthesis and tumor cell apoptosis [283,284]. Owing to its potent in vivo efficacy in a broad range of tumors, quarfloxin is currently in Phase II clinical trials as a single-agent therapy for neuroendocrine tumors.

In addition to being potential drug targets, DNA G-quadruplexes have also been shown to be potential cancer therapeutics themselves. AS1411 (Antisoma, London, UK) is a guanosine-rich 26-base G-quadruplex-forming oligonucleotide aptamer that can inhibit the growth of malignant cells by inducing apoptosis. AS1411 is currently in Phase II trials for the treatment of renal cancer and acute myeloid leukemia. AS1411 has been shown to have cancer-selective antiproliferative activity against a wide range of malignant cell types [199,285]. Finally, small molecules are not the only way to target nucleic acid structures, a high-affinity single-chain antibody has been developed which is highly specific for antiparallel telomeric repeats from Stylonychia lemnae macronuclei and binds to the telomeric repeats in vivo, not only demonstrating the concept of antibodies as ligands, but also providing one of the first key pieces of evidence that these structures are present in vivo, while the design and synthesis of new high affinity $G$ quadruplex ligands will provide new drug candidates and molecular probes $[35,286]$.

\section{Conclusions}

Both MB and NB belong to the most challenging oncologic diseases of childhood that often show poor clinical prognosis. Despite intensive multimodal therapy high-risk NB and metastatic MB frequently acquire therapy resistance with fatal clinical outcomes, hence the development of novel therapeutic approaches based on identification of specific targets seems the most promising way forward to a better outcome. There is good evidence to suggest that MYC oncogene expression and the telomere maintenance process in pediatric embryonal tumor cell populations are important in facilitating cell divisions required for cancer cell immortalized proliferation, thus making both of them attractive candidates for possible therapeutic targets. The discovery of G-quadruplex structures in specific, biologically important regions of the genome that are greatly required by cancer cells to proliferate, made them a significant drug target and ever since several compounds targeting these structures have been discovered and shown promising anticanceractivity. The therapeutic advantages of such a novel approach to anticancer drugs resides in the evidence that G-quadruplex ligands 
selectively impair the growth of cancer cells without affecting the viability of normal cells [240,244,249], together with the ability of some of these compounds to exert an antitumor activity in different in vivo models and to induce antiproliferative effects also in ALT cells [61-63]. However the compounds discovered so far are moving very slowly to the clinical setting and most of them have not yet progressed past pre-clinical investigation [287]. To advance further more efforts should be directed toward better understanding of the biological functions of G-quadruplexes in vivo, together with additional progress on the development of small molecules with realistic drug-like structures, higher selectivity and decreased side effects. Although research activity on telomeric and oncogeneic quadruplexes in embryonal tumors is still in its infancy, it is hoped that their therapeutic potential will encourage more future research in this exciting new area of molecular targeted therapy for pediatric oncology aimed towards a successful strategy for curing childhood cancer. The promise and potential is high: the challenges are considerable but surmountable.

\section{Acknowledgments}

We thank Mrs. Nicola Shalaby for the manuscript proofreading.

\section{Conflicts of Interest}

The authors declare no conflict of interest.

\section{References}

1. Legler, J.M.; Ries, L.A.; Smith, M.A.; Warren, J.L.; Heineman, E.F.; Kaplan, R.S.; Linet, M.S. Cancer surveillance series [corrected]: Brain and other central nervous system cancers: Recent trends in incidence and mortality. J. Natl. Cancer Inst. 1999, 91, 1382-1390.

2. Scotting, P.J.; Walker, D.A.; Perilongo, G. Childhood solid tumours: A developmental disorder. Nat. Rev. Cancer 2005, 5, 481-488.

3. Grimmer, M.R.; Weiss, W.A. Childhood tumors of the nervous system as disorders of normal development. Curr. Opin. Pediatr. 2006, 18, 634-638.

4. Brodeur, G.M. Neuroblastoma: Biological insights into a clinical enigma. Nat. Rev. Cancer 2003, 3, 203-216.

5. Gilbertson, R.J. Medulloblastoma: Signalling a change in treatment. Lancet Oncol. 2004, 5, 209-218.

6. Macy, M.E.; Sawczyn, K.K.; Garrington, T.P.; Graham, D.K.; Gore, L. Pediatric developmental therapies: Interesting new drugs now in early-stage clinical trials. Curr. Oncol. Rep. 2008, 10, 477-490.

7. Vassal, G. Has chemotherapy reached its limits in pediatric cancers? Eur. J. Cancer 2005, 41, $564-575$.

8. Hurley, L.H. DNA and its associated processes as targets for cancer therapy. Nat. Rev. Cancer 2002, 2, 188-200.

9. Lane, A.N.; Chaires, J.B.; Gray, R.D.; Trent, J.O. Stability and kinetics of G-quadruplex structures. Nucleic Acids Res. 2008, 36, 5482-5515. 
10. Burge, S.; Parkinson, G.N.; Hazel, P.; Todd, A.K.; Neidle, S. Quadruplex DNA: Sequence, topology and structure. Nucleic Acids Res. 2006, 34, 5402-5415.

11. Oganesian, L.; Bryan, T.M. Physiological relevance of telomeric G-quadruplex formation: A potential drug target. Bioessays 2007, 29, 155-165.

12. Qin, Y.; Hurley, L.H. Structures, folding patterns, and functions of intramolecular DNA G-quadruplexes found in eukaryotic promoter regions. Biochimie 2008, 90, 1149-1171.

13. Shukla, A.K.; Roy, K.B. Rec A-independent homologous recombination induced by a putative fold-back tetraplex DNA. Biol. Chem. 2006, 387, 251-256.

14. van Dieijen-Visser, M.P.; Go, P.M.; Brombacher, P.J. The value of laboratory tests in patients suspected of acute appendicitis. Eur. J. Clin. Chem. Clin. Biochem. 1991, 29, 749-752.

15. Gutierrez, M.L.; Crooke, S.T. Pediatric cancer chemotherapy: An updated review. I. Cis-Diammine--dichloroplatinum II (cisplatin), VM-26 (teniposide), VP-16 (etoposide), mitomycin C. Cancer Treat. Rev. 1979, 6, 153-164.

16. Gurova, K. New hopes from old drugs: Revisiting DNA-binding small molecules as anticancer agents. Future Oncol. 2009, 5, 1685-1704.

17. Cheung-Ong, K.; Giaever, G.; Nislow, C. DNA-damaging agents in cancer chemotherapy: Serendipity and chemical biology. Chem. Biol. 2013, 20, 648-659.

18. Kelland, L. The resurgence of platinum-based cancer chemotherapy. Nat. Rev. Cancer 2007, 7, 573-84.

19. Zhao, J.; Bacolla, A.; Wang, G.; Vasquez, K.M. Non-B DNA structure-induced genetic instability and evolution. Cell. Mol. Life Sci. 2010, 67, 43-62.

20. Bochman, M.L.; Paeschke, K.; Zakian, V.A. DNA secondary structures: Stability and function of G-quadruplex structures. Nat. Rev. Genet. 2012, 13, 770-780.

21. Gellert, M.; Lipsett, M.N.; Davies, D.R. Helix formation by guanylic acid. Proc. Natl. Acad. Sci. USA 1962, 48, 2013-2018.

22. Gilbert, D.E.; Feigon, J. Multistranded DNA structures. Curr. Opin. Struct. Biol. 1999, 9, 305-314.

23. Jing, N.; Li, Y.; Xiong, W.; Sha, W.; Jing, L.; Tweardy, D.J. G-quartet oligonucleotides: a new class of signal transducer and activator of transcription 3 inhibitors that suppresses growth of prostate and breast tumors through induction of apoptosis. Cancer Res. 2004, 64, 6603-6609.

24. Parkinson, G.N.; Lee, M.P.; Neidle, S. Crystal structure of parallel quadruplexes from human telomeric DNA. Nature 2002, 417, 876-880.

25. Phan, A.T.; Modi, Y.S.; Patel, D.J. Two-repeat Tetrahymena telomeric d(TGGGGTTGGGGT) Sequence interconverts between asymmetric dimeric G-quadruplexes in solution. J. Mol. Biol. 2004, 338, 93-102.

26. Kerwin, S.M. G-Quadruplex DNA as a target for drug design. Curr. Pharm. Des. 2000, 6, 441-478.

27. Phan, A.T.; Modi, Y.S.; Patel, D.J. Propeller-type parallel-stranded G-quadruplexes in the human c-myc promoter. J. Am. Chem. Soc. 2004, 126, 8710-8716.

28. Wang, Y.; Patel, D.J. Guanine residues in d(T2AG3) and d(T2G4) form parallel-stranded potassium cation stabilized G-quadruplexes with anti glycosidic torsion angles in solution. Biochemistry 1992, 31, 8112-8119. 
29. Risitano, A.; Fox, K.R. Inosine substitutions demonstrate that intramolecular DNA quadruplexes adopt different conformations in the presence of sodium and potassium. Bioorg. Med. Chem. Lett. 2005, 15, 2047-2050.

30. Fry, M. Tetraplex DNA and its interacting proteins. Front. Biosci. 2007, 12, 4336-4351.

31. Huang, W.; Smaldino, P.J.; Zhang, Q.; Miller, L.D.; Cao, P.; Stadelman, K.; Wan, M.; Giri, B.; Lei, M.; Nagamine, Y.; et al. Yin Yang 1 contains G-quadruplex structures in its promoter and 5'-UTR and its expression is modulated by G4 resolvase 1. Nucleic Acids Res. 2012, 40, 1033-1049.

32. Maizels, N. Dynamic roles for G4 DNA in the biology of eukaryotic cells. Nat. Struct. Mol. Biol. 2006, 13, 1055-1059.

33. Patel, D.J.; Phan, A.T.; Kuryavyi, V. Human telomere, oncogenic promoter and 5'-UTR G-quadruplexes: Diverse higher order DNA and RNA targets for cancer therapeutics. Nucleic Acids Res. 2007, 35, 7429-7455.

34. Schaffitzel, C.; Berger, I.; Postberg, J.; Hanes, J.; Lipps, H.J.; Pluckthun, A. In vitro generated antibodies specific for telomeric guanine-quadruplex DNA react with Stylonychia lemnae macronuclei. Proc Natl Acad Sci USA 2001, 98, 8572-8577.

35. Biffi, G.; Tannahill, D.; McCafferty, J.; Balasubramanian, S. Quantitative visualization of DNA G-quadruplex structures in human cells. Nat. Chem. 2013, 5, 182-186.

36. Grand, C.L.; Han, H.; Munoz, R.M.; Weitman, S.; Von Hoff, D.D.; Hurley, L.H.; Bearss, D.J. The cationic porphyrin TMPyP4 down-regulates c-MYC and human telomerase reverse transcriptase expression and inhibits tumor growth in vivo. Mol. Cancer Ther. 2002, 1, 565-573.

37. Seenisamy, J.; Bashyam, S.; Gokhale, V.; Vankayalapati, H.; Sun, D.; Siddiqui-Jain, A.; Streiner, N.; Shin-Ya, K.; White, E.; Wilson, W.D.; et al. Design and synthesis of an expanded porphyrin that has selectivity for the c-MYC G-quadruplex structure. J. Am. Chem. Soc. 2005, 127, 2944-2959.

38. Kostadinov, R.; Malhotra, N.; Viotti, M.; Shine, R.; D'Antonio, L.; Bagga, P. GRSDB: A database of quadruplex forming G-rich sequences in alternatively processed mammalian pre-mRNA sequences. Nucleic Acids Res. 2006, 34, D119-D124.

39. Zarudnaya, M.I.; Kolomiets, I.M.; Potyahaylo, A.L.; Hovorun, D.M. Downstream elements of mammalian pre-mRNA polyadenylation signals: Primary, secondary and higher-order structures. Nucleic Acids Res. 2003, 31, 1375-1386.

40. Davis, T.L.; Firulli, A.B.; Kinniburgh, A.J. Ribonucleoprotein and protein factors bind to an H-DNA-forming c-myc DNA element: Possible regulators of the c-myc gene. Proc. Natl. Acad. Sci. USA 1989, 86, 9682-9686.

41. Ou, T.M.; Lin, J.; Lu, Y.J.; Hou, J.Q.; Tan, J.H.; Chen, S.H.; Li, Z.; Li, Y.P.; Li, D.; Gu, L.Q.; et al. Inhibition of cell proliferation by quindoline derivative (SYUIQ-05) through its preferential interaction with c-myc promoter G-quadruplex. J. Med. Chem. 2011, 54, 5671-5679.

42. Murat, P.; Singh, Y.; Defrancq, E. Methods for investigating G-quadruplex DNA/ligand interactions. Chem. Soc. Rev. 2011, 40, 5293-5307.

43. Yuan, L.; Tian, T.; Chen, Y.; Yan, S.; Xing, X.; Zhang, Z.; Zhai, Q.; Xu, L.; Wang, S.; Weng, X.; et al. Existence of G-quadruplex structures in promoter region of oncogenes confirmed by G-quadruplex DNA cross-linking strategy. Sci. Rep. 2013, 3, 1811.

44. Blackburn, E.H. Telomere states and cell fates. Nature 2000, 408, 53-56. 
45. Hackett, J.A.; Feldser, D.M.; Greider, C.W. Telomere dysfunction increases mutation rate and genomic instability. Cell 2001, 106, 275-286.

46. Van Steensel, B.; Smogorzewska, A.; de Lange, T. TRF2 protects human telomeres from end-to-end fusions. Cell 1998, 92, 401-413.

47. Chai, W.; Du, Q.; Shay, J.W.; Wright, W.E. Human telomeres have different overhang sizes at leading versus lagging strands. Mol. Cell 2006, 21, 427-435.

48. Zhao, Y.; Hoshiyama, H.; Shay, J.W.; Wright, W.E. Quantitative telomeric overhang determination using a double-strand specific nuclease. Nucleic Acids Res. 2008, 36, e14.

49. Blasco, M.A. Telomeres and human disease: Ageing, cancer and beyond. Nat. Rev. Genet. 2005, 6, 611-22.

50. Shin, J.S.; Hong, A.; Solomon, M.J.; Lee, C.S. The role of telomeres and telomerase in the pathology of human cancer and aging. Pathology 2006, 38, 103-113.

51. de Lange, T. Shelterin: The protein complex that shapes and safeguards human telomeres. Genes Dev. 2005, 19, 2100-10.

52. Wang, F.; Podell, E.R.; Zaug, A.J.; Yang, Y.; Baciu, P.; Cech, T.R.; Lei, M. The POT1-TPP1 telomere complex is a telomerase processivity factor. Nature 2007, 445, 506-510.

53. Morin, G.B. Telomere control of replicative lifespan. Exp. Gerontol. 1997, 32, 375-382.

54. Olovnikov, A.M. A theory of marginotomy. The incomplete copying of template margin in enzymic synthesis of polynucleotides and biological significance of the phenomenon. $J$. Theor. Biol. 1973, 41, 181-190.

55. Feng, J.; Funk, W.D.; Wang, S.S.; Weinrich, S.L.; Avilion, A.A.; Chiu, C.P.; Adams, R.R.; Chang, E.; Allsopp, R.C.; Yu, J.; et al. The RNA component of human telomerase. Science 1995, 269, 1236-1241.

56. Bosoy, D.; Peng, Y.; Mian, I.S.; Lue, N.F. Conserved N-terminal Motifs of Telomerase Reverse Transcriptase Required for Ribonucleoprotein Assembly in Vivo. J. Biol. Chem. 2003, 278, 3882-3890.

57. Masutomi, K.; Yu, E.Y.; Khurts, S.; Ben-Porath, I.; Currier, J.L.; Metz, G.B.; Brooks, M.W.; Kaneko, S.; Murakami, S.; de Caprio, J.A.; et al. Telomerase maintains telomere structure in normal human cells. Cell 2003, 114, 241-253.

58. Blackburn, E.H.; Greider, C.W.; Szostak, J.W. Telomeres and telomerase: The path from maize, Tetrahymena and yeast to human cancer and aging. Nat. Med. 2006, 12, 1133-1138.

59. Forsyth, N.R.; Wright, W.E.; Shay, J.W. Telomerase and differentiation in multicellular organisms: Turn it off, turn it on, and turn it off again. Differentiation 2002, 69, 188-197.

60. Harrington, L. Does the reservoir for self-renewal stem from the ends? Oncogene 2004, 23, 7283-7289.

61. Henson, J.D.; Neumann, A.A.; Yeager, T.R.; Reddel, R.R. Alternative lengthening of telomeres in mammalian cells. Oncogene 2002, 21, 598-610.

62. Neumann, A.A.; Reddel, R.R. Telomere maintenance and cancer? Look, no telomerase. Nat. Rev. Cancer 2002, 2, 879-884.

63. Dunham, M.A.; Neumann, A.A.; Fasching, C.L.; Reddel, R.R. Telomere maintenance by recombination in human cells. Nat. Genet. 2000, 26, 447-450. 
64. Schaetzlein, S.; Lucas-Hahn, A.; Lemme, E.; Kues, W.A.; Dorsch, M.; Manns, M.P.; Niemann, H.; Rudolph, K.L. Telomere length is reset during early mammalian embryogenesis. Proc. Natl. Acad. Sci. USA 2004, 101, 8034-8038.

65. De Lange, T.; Shiue, L.; Myers, R.M.; Cox, D.R.; Naylor, S.L.; Killery, A.M.; Varmus, H.E. Structure and variability of human chromosome ends. Mol. Cell. Biol. 1990, 10, 518-527.

66. Achi, M.V.; Ravindranath, N.; Dym, M. Telomere length in male germ cells is inversely correlated with telomerase activity. Biol. Reprod. 2000, 63, 591-598.

67. Hemann, M.T.; Rudolph, K.L.; Strong, M.A.; DePinho, R.A.; Chin, L.; Greider, C.W. Telomere dysfunction triggers developmentally regulated germ cell apoptosis. Mol. Biol. Cell. 2001, 12, 2023-2030.

68. Stindl, R. Is telomere erosion a mechanism of species extinction? J. Exp. Zoolog. B Mol. Dev. Evol. 2004, 302, 111-120.

69. Allsopp, R.C.; Vaziri, H.; Patterson, C.; Goldstein, S.; Younglai, E.V.; Futcher, A.B.; Greider, C.W.; Harley, C.B. Telomere length predicts replicative capacity of human fibroblasts. Proc. Natl. Acad. Sci. USA 1992, 89, 10114-1018.

70. Cooke, H.J.; Smith, B.A. Variability at the telomeres of the human X/Y pseudoautosomal region. Cold Spring Harb. Symp. Quant. Biol. 1986, 51 (Pt 1), 213-219.

71. Dahse, R.; Fiedler, W.; Ernst, G. Telomeres and telomerase: Biological and clinical importance. Clin. Chem. 1997, 43, 708-714.

72. Blasco, M.A.; Funk, W.; Villeponteau, B.; Greider, C.W. Functional characterization and developmental regulation of mouse telomerase RNA. Science 1995, 269, 1267-1270.

73. Wright, W.E.; Piatyszek, M.A.; Rainey, W.E.; Byrd, W.; Shay, J.W. Telomerase activity in human germline and embryonic tissues and cells. Dev. Genet. 1996, 18, 173-179.

74. Yashima, K.; Maitra, A.; Rogers, B.B.; Timmons, C.F.; Rathi, A.; Pinar, H.; Wright, W.E.; Shay, J.W.; Gazdar, A.F. Expression of the RNA component of telomerase during human development and differentiation. Cell. Growth Differ. 1998, 9, 805-813.

75. Ulaner, G.A.; Hu, J.F.; Vu, T.H.; Giudice, L.C.; Hoffman, A.R. Telomerase activity in human development is regulated by human telomerase reverse transcriptase (hTERT) transcription and by alternate splicing of hTERT transcripts. Cancer Res. 1998, 58, 4168-4172.

76. Hiyama, E.; Hiyama, K. Telomere and telomerase in stem cells. Br. J. Cancer 2007, 96, 1020-1024.

77. Sugihara, M.; Ohshima, K.; Nakamura, H.; Suzumiya, J.; Nakayama, Y.; Kanda, M.; Haraoka, S.; Kikuchi, M. Decreased expression of telomerase-associated RNAs in the proliferation of stem cells in comparison with continuous expression in malignant tumors. Int. J. Oncol. 1999, 15, 1075-1080.

78. Haas, O.A.; Seyger, M. Hypothesis: meiotic origin of trisomic neoplasms. Cancer Genet. Cytogenet. 1993, 70, 112-116.

79. Lampert, F. On the "keimversprengungs" origin of embryonic tumors. Cancer Genet. Cytogenet. 1994, 78, 242.

80. Trosko, J.E. Review paper: Cancer stem cells and cancer nonstem cells: From adult stem cells or from reprogramming of differentiated somatic cells. Vet. Pathol. 2009, 46, 176-193. 
81. Kim, N.W.; Piatyszek, M.A.; Prowse, K.R.; Harley, C.B.; West, M.D.; Ho, P.L.; Coviello, G.M.; Wright, W.E.; Weinrich, S.L.; Shay, J.W. Specific association of human telomerase activity with immortal cells and cancer. Science 1994, 266, 2011-2015.

82. Counter, C.M.; Avilion, A.A.; LeFeuvre, C.E.; Stewart, N.G.; Greider, C.W.; Harley, C.B.; Bacchetti, S. Telomere shortening associated with chromosome instability is arrested in immortal cells which express telomerase activity. EMBO J. 1992, 11, 1921-1929.

83. Hiyama, E.; Hiyama, K. Clinical utility of telomerase in cancer. Oncogene 2002, 21, 643-649.

84. Harley, C.B.; Futcher, A.B.; Greider, C.W. Telomeres shorten during ageing of human fibroblasts. Nature 1990, 345, 458-460.

85. Hiyama, E.; Hiyama, K.; Yokoyama, T.; Matsuura, Y.; Piatyszek, M.A.; Shay, J.W. Correlating telomerase activity levels with human neuroblastoma outcomes. Nat. Med. 1995, 1, 249-255.

86. Greaves, M. Is telomerase activity in cancer due to selection of stem cells and differentiation arrest? Trends Genet. 1996, 12, 127-128.

87. Armstrong, L.; Saretzki, G.; Peters, H.; Wappler, I.; Evans, J.; Hole, N.; von Zglinicki, T.; Lako, M. Overexpression of telomerase confers growth advantage, stress resistance, and enhanced differentiation of ESCs toward the hematopoietic lineage. Stem Cells 2005, 23, 516-529.

88. O'Brien, C.A.; Pollett, A.; Gallinger, S.; Dick, J.E. A human colon cancer cell capable of initiating tumour growth in immunodeficient mice. Nature 2007, 445, 106-110.

89. Mishra, L.; Banker, T.; Murray, J.; Byers, S.; Thenappan, A.; He, A.R.; Shetty, K.; Johnson, L.; Reddy, E.P. Liver stem cells and hepatocellular carcinoma. Hepatology 2009, 49, 318-329.

90. Grichnik, J.M. Melanoma, nevogenesis, and stem cell biology. J. Invest. Dermatol. 2008, 128, 2365-2380.

91. Trumpp, A.; Wiestler, O.D. Mechanisms of Disease: Cancer stem cells--targeting the evil twin. Nat. Clin. Pract. Oncol. 2008, 5, 337-347.

92. Read, T.A.; Fogarty, M.P.; Markant, S.L.; McLendon, R.E.; Wei, Z.; Ellison, D.W.; Febbo, P.G.; Wechsler-Reya, R.J. Identification of CD15 as a marker for tumor-propagating cells in a mouse model of medulloblastoma. Cancer Cell. 2009, 15, 135-147.

93. Cairo, S.; Armengol, C.; de Reynies, A.; Wei, Y.; Thomas, E.; Renard, C.A.; Goga, A.; Balakrishnan, A.; Semeraro, M.; Gresh, L.; et al. Hepatic stem-like phenotype and interplay of Wnt/beta-catenin and Myc signaling in aggressive childhood liver cancer. Cancer Cell. 2008, 14, 471-484.

94. Charytonowicz, E.; Cordon-Cardo, C.; Matushansky, I.; Ziman, M. Alveolar rhabdomyosarcoma: Is the cell of origin a mesenchymal stem cell? Cancer Lett. 2009, 279, 126-136.

95. Fan, X.; Eberhart, C.G. Medulloblastoma stem cells. J. Clin. Oncol. 2008, 26, 2821-2827.

96. Ross, R.A.; Spengler, B.A. Human neuroblastoma stem cells. Semin. Cancer Biol. 2007, 17, 241-247.

97. Suva, M.L.; Riggi, N.; Stehle, J.C.; Baumer, K.; Tercier, S.; Joseph, J.M.; Suva, D.; Clement, V.; Provero, P.; Cironi, L.; Osterheld, M.C.; Guillou, L.; Stamenkovic, I. Identification of cancer stem cells in Ewing's sarcoma. Cancer Res. 2009, 69, 1776-1781.

98. Allen, N.D.; Baird, D.M. Telomere length maintenance in stem cell populations. Biochim. Biophys. Acta 2009, 1792, 324-328. 
99. Sabatier, L.; Ricoul, M.; Pottier, G.; Murnane, J.P. The loss of a single telomere can result in instability of multiple chromosomes in a human tumor cell line. Mol. Cancer Res. 2005, 3, 139-150.

100. Brunori, M.; Mathieu, N.; Ricoul, M.; Bauwens, S.; Koering, C.E.; Roborel de Climens, A.; Belleville, A.; Wang, Q.; Puisieux, I.; Decimo, D.; Puisieux, A.; Sabatier, L.; Gilson, E. TRF2 inhibition promotes anchorage-independent growth of telomerase-positive human fibroblasts. Oncogene 2006, 25, 990-997.

101. Blackburn, E.H. Structure and function of telomeres. Nature 1991, 350, 569-573.

102. Hande, M.P.; Samper, E.; Lansdorp, P.; Blasco, M.A. Telomere length dynamics and chromosomal instability in cells derived from telomerase null mice. J. Cell. Biol. 1999, 144, 589-601.

103. Velicescu, M.; Yu, J.; Herbert, B.S.; Shay, J.W.; Granada, E.; Dubeau, L. Aneuploidy and telomere attrition are independent determinants of crisis in SV40-transformed epithelial cells. Cancer Res. 2003, 63, 5813-5820.

104. Gisselsson, D.; Pettersson, L.; Hoglund, M.; Heidenblad, M.; Gorunova, L.; Wiegant, J.; Mertens, F.; Dal Cin, P.; Mitelman, F.; Mandahl, N. Chromosomal breakage-fusion-bridge events cause genetic intratumor heterogeneity. Proc. Natl. Acad. Sci. USA 2000, 97, 5357-5362.

105. Stewenius, Y.; Gorunova, L.; Jonson, T.; Larsson, N.; Hoglund, M.; Mandahl, N.; Mertens, F.; Mitelman, F.; Gisselsson, D. Structural and numerical chromosome changes in colon cancer develop through telomere-mediated anaphase bridges, not through mitotic multipolarity. Proc. Natl. Acad. Sci. USA 2005, 102, 5541-5546.

106. Fett-Conte, A.C.; Liedtke Junior, H.; Chaves, H.; Thome, J.A.; Tajara, E.H. Telomeric fusions in a Wilms' tumor. Cancer Genet. Cytogenet. 1993, 69, 141-145.

107. Stewenius, Y.; Jin, Y.; Ora, I.; de Kraker, J.; Bras, J.; Frigyesi, A.; Alumets, J.; Sandstedt, B.; Meeker, A.K.; Gisselsson, D. Defective chromosome segregation and telomere dysfunction in aggressive Wilms' tumors. Clin. Cancer Res. 2007, 13, 6593-6602.

108. Frappart, P.O.; Lee, Y.; Russell, H.R.; Chalhoub, N.; Wang, Y.D.; Orii, K.E.; Zhao, J.; Kondo, N.; Baker, S.J.; McKinnon, P.J. Recurrent genomic alterations characterize medulloblastoma arising from DNA double-strand break repair deficiency. Proc. Natl. Acad. Sci. USA 2009, 106, $1880-1885$.

109. Shakhova, O.; Leung, C.; van Montfort, E.; Berns, A.; Marino, S. Lack of Rb and p53 delays cerebellar development and predisposes to large cell anaplastic medulloblastoma through amplification of N-Myc and Ptch2. Cancer Res. 2006, 66, 5190-5200.

110. Schulte, J.H.; Kuhfittig-Kulle, S.; Klein-Hitpass, L.; Schramm, A.; Biard, D.S.; Pfeiffer, P.; Eggert, A. Expression of the TrkA or TrkB receptor tyrosine kinase alters the double-strand break (DSB) repair capacity of SY5Y neuroblastoma cells. DNA Repair 2008, 7, 1757-1764.

111. Sugihara, E.; Kanai, M.; Matsui, A.; Onodera, M.; Schwab, M.; Miwa, M. Enhanced expression of MYCN leads to centrosome hyperamplification after DNA damage in neuroblastoma cells. Oncogene 2004, 23, 1005-1009.

112. Goldstein, M.; Meller, I.; Issakov, J.; Orr-Urtreger, A. Novel genes implicated in embryonal, alveolar, and pleomorphic rhabdomyosarcoma: A cytogenetic and molecular analysis of primary tumors. Neoplasia. 2006, 8, 332-343. 
113. Wang, Z.; Velagaleti, G.V.; Eltorky, M.A.; Tang, W.W.; Hawkins, H.K.; Jones, E.A.; Northup, J.; Panova, N.; Qiu, S. Cytogenetic and molecular studies of an unusual case of multiple primary alveolar rhabdomyosarcomas: Low-level chromosomal instability and reciprocal translocation t(6;11). Exp. Mol. Pathol. 2007, 82, 58-62.

114. Rahman, R.; Heath, R.; Grundy, R. Cellular immortality in brain tumours: An integration of the cancer stem cell paradigm. Biochim. Biophys. Acta. 2009, 1792, 280-288.

115. Polychronopoulou, S.; Koutroumba, P. Telomere length and telomerase activity: Variations with advancing age and potential role in childhood malignancies. J. Pediatr. Hematol. Oncol. 2004, 26, 342-350.

116. Bianchi, A.; Shore, D. How telomerase reaches its end: Mechanism of telomerase regulation by the telomeric complex. Mol. Cell. 2008, 31, 153-165.

117. Guittat, L.; Alberti, P.; Gomez, D.; De Cian, A.; Pennarun, G.; Lemarteleur, T.; Belmokhtar, C.; Paterski, R.; Morjani, H.; Trentesaux, C.; et al. Targeting human telomerase for cancer therapeutics. Cytotechnology. 2004, 45, 75-90.

118. Harley, C.B. Telomerase and cancer therapeutics. Nat. Rev. Cancer 2008, 8, 167-79.

119. Rankin, A.M.; Faller, D.V.; Spanjaard, R.A. Telomerase inhibitors and 'T-oligo' as cancer therapeutics: Contrasting molecular mechanisms of cytotoxicity. Anticancer Drugs 2008, 19, 329-338.

120. Sawyer, J.R.; Goosen, L.S.; Stine, K.C.; Thomas, J.R. Telomere fusion as a mechanism for the progressive loss of the short arm of chromosome 11 in an anaplastic Wilms' tumor. Cancer 1994, 74, 767-773.

121. Ulaner, G.A.; Hoffman, A.R.; Otero, J.; Huang, H.Y.; Zhao, Z.; Mazumdar, M.; Gorlick, R.; Meyers, P.; Healey, J.H.; Ladanyi, M. Divergent patterns of telomere maintenance mechanisms among human sarcomas: Sharply contrasting prevalence of the alternative lengthening of telomeres mechanism in Ewing's sarcomas and osteosarcomas. Genes Chromosomes Cancer 2004, 41, 155-162.

122. Yan, P.; Benhattar, J.; Coindre, J.M.; Guillou, L. Telomerase activity and hTERT mRNA expression can be heterogeneous and does not correlate with telomere length in soft tissue sarcomas. Int. J. Cancer 2002, 98, 851-856.

123. Ohali, A.; Avigad, S.; Cohen, I.J.; Meller, I.; Kollender, Y.; Issakov, J.; Gelernter, I.; Goshen, Y.; Yaniv, I.; Zaizov, R. Association between telomerase activity and outcome in patients with nonmetastatic Ewing family of tumors. J. Clin. Oncol. 2003, 21, 3836-3843.

124. Hiyama, E.; Yamaoka, H.; Matsunaga, T.; Hayashi, Y.; Ando, H.; Suita, S.; Horie, H.; Kaneko, M.; Sasaki, F.; Hashizume, K.; Nakagawara, A.; Ohnuma, N.; Yokoyama, T. High expression of telomerase is an independent prognostic indicator of poor outcome in hepatoblastoma. $\mathrm{Br}$. $\mathrm{J}$. Cancer 2004, 91, 972-979.

125. Yan, C.T.; Kaushal, D.; Murphy, M.; Zhang, Y.; Datta, A.; Chen, C.; Monroe, B.; Mostoslavsky, G.; Coakley, K.; Gao, Y.; et al. XRCC4 suppresses medulloblastomas with recurrent translocations in p53-deficient mice. Proc. Natl. Acad. Sci. USA 2006, 103, 7378-7383.

126. Zindy, F.; Uziel, T.; Ayrault, O.; Calabrese, C.; Valentine, M.; Rehg, J.E.; Gilbertson, R.J.; Sherr, C.J.; Roussel, M.F. Genetic alterations in mouse medulloblastomas and generation of tumors de novo from primary cerebellar granule neuron precursors. Cancer Res. 2007, 67, 2676-2684. 
127. Hiyama, E.; Hiyama, K.; Ohtsu, K.; Yamaoka, H.; Ichikawa, T.; Shay, J.W.; Yokoyama, T. Telomerase activity in neuroblastoma: Is it a prognostic indicator of clinical behaviour? Eur. J. Cancer 1997, 33, 1932-1936.

128. Dome, J.S.; Chung, S.; Bergemann, T.; Umbricht, C.B.; Saji, M.; Carey, L.A.; Grundy, P.E.; Perlman, E.J.; Breslow, N.E.; Sukumar, S. High telomerase reverse transcriptase (hTERT) messenger RNA level correlates with tumor recurrence in patients with favorable histology Wilms' tumor. Cancer Res. 1999, 59, 4301-4307.

129. Montgomery, E.; Argani, P.; Hicks, J.L.; DeMarzo, A.M.; Meeker, A.K. Telomere lengths of translocation-associated and nontranslocation-associated sarcomas differ dramatically. Am. J. Pathol. 2004, 164, 1523-1529.

130. Sawada, T.; Kidowaki, T.; Sakamoto, I.; Hashida, T.; Matsumura, T.; Nakagawa, M.; Kusunoki, T. Neuroblastoma. Mass screening for early detection and its prognosis. Cancer 1984, 53, 2731-2735.

131. Schwab, M.; Westermann, F.; Hero, B.; Berthold, F. Neuroblastoma: Biology and molecular and chromosomal pathology. Lancet Oncol. 2003, 4, 472-480.

132. Ponzielli, R.; Katz, S.; Barsyte-Lovejoy, D.; Penn, L.Z. Cancer therapeutics: Targeting the dark side of Myc. Eur. J. Cancer 2005, 41, 2485-2501.

133. Westermann, F.; Schwab, M. Genetic parameters of neuroblastomas. Cancer Lett. 2002, 184, 127-147.

134. Riley, R.D.; Heney, D.; Jones, D.R.; Sutton, A.J.; Lambert, P.C.; Abrams, K.R.; Young, B.; Wailoo, A.J.; Burchill, S.A. A systematic review of molecular and biological tumor markers in neuroblastoma. Clin. Cancer Res. 2004, 10, 4-12.

135. Hiyama, E.; Hiyama, K.; Yokoyama, T.; Ichikawa, T.; Matsuura, Y. Length of telomeric repeats in neuroblastoma: Correlation with prognosis and other biological characteristics. Jpn. J. Cancer Res. 1992, 83, 159-164.

136. Poremba, C.; Willenbring, H.; Hero, B.; Christiansen, H.; Schafer, K.L.; Brinkschmidt, C.; Jurgens, H.; Bocker, W.; Dockhorn-Dworniczak, B. Telomerase activity distinguishes between neuroblastomas with good and poor prognosis. Ann. Oncol. 1999, 10, 715-721.

137. Brinkschmidt, C.; Poremba, C.; Christiansen, H.; Simon, R.; Schafer, K.L.; Terpe, H.J.; Lampert, F.; Boecker, W.; Dockhorn-Dworniczak, B. Comparative genomic hybridization and telomerase activity analysis identify two biologically different groups of $4 \mathrm{~s}$ neuroblastomas. $\mathrm{Br}$. J. Cancer 1998, 77, 2223-2229.

138. Reynolds, C.P.; Zuo, J.J.; Kim, N.W.; Wang, H.; Lukens, J.N.; Matthay, K.K.; Seeger, R.C. Telomerase expression in primary neuroblastomas. Eur. J. Cancer 1997, 33, 1929-1931.

139. Streutker, C.J.; Thorner, P.; Fabricius, N.; Weitzman, S.; Zielenska, M. Telomerase activity as a prognostic factor in neuroblastomas. Pediatr. Dev. Pathol. 2001, 4, 62-67.

140. Poremba, C.; Hero, B.; Heine, B.; Scheel, C.; Schaefer, K.L.; Christiansen, H.; Berthold, F.; Kneif, S.; Stein, H.; Juergens, H.; Boecker, W.; Dockhorn-Dworniczak, B. Telomerase is a strong indicator for assessing the proneness to progression in neuroblastomas. Med. Pediatr. Oncol. 2000, 35, 651-655.

141. Maitra, A.; Yashima, K.; Rathi, A.; Timmons, C.F.; Rogers, B.B.; Shay, J.W.; Gazdar, A.F. The RNA component of telomerase as a marker of biologic potential and clinical outcome in childhood neuroblastic tumors. Cancer 1999, 85, 741-749. 
142. Krams, M.; Hero, B.; Berthold, F.; Parwaresch, R.; Harms, D.; Rudolph, P. Full-length telomerase reverse transcriptase messenger RNA is an independent prognostic factor in neuroblastoma. Am. J. Pathol. 2003, 162, 1019-1026.

143. Binz, N.; Shalaby, T.; Rivera, P.; Shin-ya, K.; Grotzer, M.A. Telomerase inhibition, telomere shortening, cell growth suppression and induction of apoptosis by telomestatin in childhood neuroblastoma cells. Eur. J. Cancer 2005, 41, 2873-2881.

144. Byrd, T.; Grossman, R.G.; Ahmed, N. Medulloblastoma-biology and microenvironment: A review. Pediatr. Hematol. Oncol. 2012, 29, 495-506.

145. Eberhart, C.G.; Kratz, J.E.; Schuster, A.; Goldthwaite, P.; Cohen, K.J.; Perlman, E.J.; Burger, P.C. Comparative genomic hybridization detects an increased number of chromosomal alterations in large cell/anaplastic medulloblastomas. Brain Pathol. 2002, 12, 36-44.

146. Reardon, D.A.; Michalkiewicz, E.; Boyett, J.M.; Sublett, J.E.; Entrekin, R.E.; Ragsdale, S.T.; Valentine, M.B.; Behm, F.G.; Li, H.; Heidemann, R.L.; Kun, L.E.; Shapiro, D.N.; Look, A.T. Extensive genomic abnormalities in childhood medulloblastoma by comparative genomic hybridization. Cancer Research 1997, 57, 4042-4047.

147. Fan, X.; Wang, Y.; Kratz, J.; Brat, D.J.; Robitaille, Y.; Moghrabi, A.; Perlman, E.J.; Dang, C.V.; Burger, P.C.; Eberhart, C.G. hTERT gene amplification and increased mRNA expression in central nervous system embryonal tumors. Am. J. Pathol. 2003, 162, 1763-1769.

148. Didiano, D.; Shalaby, T.; Lang, D.; Grotzer, M.A. Telomere maintenance in childhood primitive neuroectodermal brain tumors. J. Neurooncol. 2004, 6, 1-8.

149. Liu, J.; Guo, L.; Luo, Y.; Li, J.W.; Li, H. All trans-retinoic acid suppresses in vitro growth and down-regulates LIF gene expression as well as telomerase activity of human medulloblastoma cells. Anticancer Res. 2000, 20, 2659-2664.

150. Hiraga, S.; Ohnishi, T.; Izumoto, S.; Miyahara, E.; Kanemura, Y.; Matsumura, H.; Arita, N. Telomerase activity and alterations in telomere length in human brain tumors. Cancer Research 1998, 58, 2117-2125.

151. DeMasters, B.K.; Markham, N.; Lillehei, K.O.; Shroyer, K.R. Differential telomerase expression in human primary intracranial tumors. Am. J. Clin. Pathol. 1997, 107, 548-554.

152. Sugita, Y.; Nakashima, A.; Kato, S.; Sakata, K.; Morimatsu, M.; Shigemori, M. Telomerase activity in gliomas with the use of non-radioisotopic and semi-quantitative procedure for terminal repeat amplification protocol. Oncol Rep. 2000, 7, 1087-1092.

153. Falchetti, M.L.; Pallini, R.; Larocca, L.M.; Verna, R.; D'Ambrosio, E. Telomerase expression in intracranial tumours: Prognostic potential for malignant gliomas and meningiomas. J. Clin. Pathol. 1999, 52, 234-236.

154. Zimmerman, K.; Alt, F.W. Expression and function of myc family genes. Crit. Rev. Oncog. 1990, 2, 75-95.

155. Caren, H.; Kryh, H.; Nethander, M.; Sjoberg, R.M.; Trager, C.; Nilsson, S.; Abrahamsson, J.; Kogner, P.; Martinsson, T. High-risk neuroblastoma tumors with 11q-deletion display a poor prognostic, chromosome instability phenotype with later onset. Proc. Natl. Acad. Sci. USA 2010, $107,4323-4328$. 
156. Westermann, F.; Muth, D.; Benner, A.; Bauer, T.; Henrich, K.O.; Oberthuer, A.; Brors, B.; Beissbarth, T.; Vandesompele, J.; Pattyn, F.; Hero, B.; Konig, R.; Fischer, M.; Schwab, M. Distinct transcriptional MYCN/c-MYC activities are associated with spontaneous regression or malignant progression in neuroblastomas. Genome Biol. 2008, 9, R150.

157. Fredlund, E.; Ringner, M.; Maris, J.M.; Pahlman, S. High Myc pathway activity and low stage of neuronal differentiation associate with poor outcome in neuroblastoma. Proc. Natl. Acad. Sci. USA 2008, 105, 14094-14099.

158. Westermark, U.K.; Wilhelm, M.; Frenzel, A.; Henriksson, M.A. The MYCN oncogene and differentiation in neuroblastoma. Semin. Cancer Biol. 2011, 21, 256-266.

159. Burkhart, C.A.; Cheng, A.J.; Madafiglio, J.; Kavallaris, M.; Mili, M.; Marshall, G.M.; Weiss, W.A.; Khachigian, L.M.; Norris, M.D.; Haber, M. Effects of MYCN antisense oligonucleotide administration on tumorigenesis in a murine model of neuroblastoma. J. Natl. Cancer Inst. 2003, 95, 1394-1403.

160. Kang, J.H.; Rychahou, P.G.; Ishola, T.A.; Qiao, J.; Evers, B.M.; Chung, D.H. MYCN silencing induces differentiation and apoptosis in human neuroblastoma cells. Biochem. Biophys. Res. Commun. 2006, 351, 192-197.

161. Nara, K.; Kusafuka, T.; Yoneda, A.; Oue, T.; Sangkhathat, S.; Fukuzawa, M. Silencing of MYCN by RNA interference induces growth inhibition, apoptotic activity and cell differentiation in a neuroblastoma cell line with MYCN amplification. Int. J. Oncol. 2007, 30, 1189-1196.

162. Negroni, A.; Scarpa, S.; Romeo, A.; Ferrari, S.; Modesti, A.; Raschella, G. Decrease of proliferation rate and induction of differentiation by a MYCN antisense DNA oligomer in a human neuroblastoma cell line. Cell. Growth Differ. 1991, 2, 511-518.

163. Pession, A.; Tonelli, R.; Fronza, R.; Sciamanna, E.; Corradini, R.; Sforza, S.; Tedeschi, T.; Marchelli, R.; Montanaro, L.; Camerin, C.; Franzoni, M.; Paolucci, G. Targeted inhibition of NMYC by peptide nucleic acid in N-myc amplified human neuroblastoma cells: Cell-cycle inhibition with induction of neuronal cell differentiation and apoptosis. Int. J. Oncol. 2004, 24, 265-272.

164. Ponthan, F.; Lindskog, M.; Karnehed, N.; Castro, J.; Kogner, P. Evaluation of anti-tumour effects of oral fenretinide (4-HPR) in rats with human neuroblastoma xenografts. Oncol. Rep. 2003, 10, 1587-1592.

165. Sun, L.; Fuselier, J.A.; Murphy, W.A.; Coy, D.H. Antisense peptide nucleic acids conjugated to somatostatin analogs and targeted at the n-myc oncogene display enhanced cytotoxity to human neuroblastoma IMR32 cells expressing somatostatin receptors. Peptides 2002, 23, 1557-1565.

166. Grotzer, M.A.; Hogarty, M.D.; Janss, A.J.; Liu, X.; Zhao, H.; Eggert, A.; Sutton, L.N.; Rorke, L.B.; Brodeur, G.M.; Phillips, P.C. MYC messenger RNA expression predicts survival outcome in childhood primitive neuroectodermal tumor/medulloblastoma. Clin. Cancer Res. 2001, 7, 2425-2433.

167. Eberhart, C.G.; Kratz, J.; Wang, Y.; Summers, K.; Stearns, D.; Cohen, K.; Dang, C.V.; Burger, P.C. Histopathological and molecular prognostic markers in medulloblastoma: C-myc, N-myc, TrkC, and anaplasia. J. Neuropathol. Exp. Neurol. 2004, 63, 441-449.

168. Pession, A.; Tonelli, R. The MYCN oncogene as a specific and selective drug target for peripheral and central nervous system tumors. Curr. Cancer Drug Targets 2005, 5, 273-283. 
169. Brandes, A.A.; Palmisano, V.; Monfardini, S. Medulloblastoma in adults: Clinical characteristics and treatment. Cancer Treat. Rev. 1999, 25, 3-12.

170. Frühwald, M.C.; D'Orisio, M.S.; Dai, Z.; Rush, L.J.; Krahe, R.; Smiraglia, D.J.; Pietsch, T.; Elsea, S.H.; Plass, C. Aberrant hypermethylation of the major breakpoint cluster region in 17 p11.2 in medulloblastoma but not supratentorial PNETs. Genes Chromosomes Cancer 2001, $30,38-47$.

171. Aldosari, N.; Bigner, S.H.; Burger, P.C.; Becker, L.; Kepner, J.L.; Friedman, H.S.; McLendon, R.E. MYCC and MYCN oncogene amplification in medulloblastoma. A fluorescence in situ hybridization study on paraffin sections from the Children's Oncology Group. Arch. Pathol. Lab. Med. 2002, 126, 540-545.

172. Rutkowski, S.; von Bueren, A.; von Hoff, K.; Hartmann, W.; Shalaby, T.; Deinlein, F.; Warmuth-Metz, M.; Soerensen, N.; Emser, A.; Bode, U.; Mittler, U.; Urban, C.; Benesch, M.; Kortmann, R.D.; Schlegel, P.G.; Kuehl, J.; Pietsch, T.; Grotzer, M. Prognostic Relevance of Clinical and Biological Risk Factors in Childhood Medulloblastoma: Results of Patients Treated in the Prospective Multicenter Trial HIT'91. Clin. Cancer Res. 2007, 13, 2651-2657.

173. Brown, H.G.; Kepner, J.L.; Perlman, E.J.; Friedman, H.S.; Strother, D.R.; Duffner, P.K.; Kun, L.E.; Goldthwaite, P.T.; Burger, P.C. "Large cell/anaplastic" medulloblastomas: A Pediatric Oncology Group Study. J. Neuropathol. Exp. Neurol. 2000, 59, 857-865.

174. Kenney, A.M.; Cole, M.D.; Rowitch, D.H. Nmyc upregulation by sonic hedgehog signaling promotes proliferation in developing cerebellar granule neuron precursors. Development 2003, $130,15-28$.

175. Oliver, T.G.; Grasfeder, L.L.; Carroll, A.L.; Kaiser, C.; Gillingham, C.L.; Lin, S.M.; Wickramasinghe, R.; Scott, M.P.; Wechsler-Reya, R.J. Transcriptional profiling of the Sonic hedgehog response: A critical role for N-myc in proliferation of neuronal precursors. Proc. Natl. Acad. Sci. USA 2003, 100, 7331-7336.

176. Rao, G.; Pedone, C.A.; Coffin, C.M.; Holland, E.C.; Fults, D.W. c-Myc enhances sonic hedgehog-induced medulloblastoma formation from nestin-expressing neural progenitors in mice. Neoplasia. 2003, 5, 198-204.

177. Guessous, F.; Li, Y.; Abounader, R. Signaling pathways in medulloblastoma. J. Cell. Physiol. 2008, 217, 577-583.

178. Zhang, P.; Li, H.; Wu, M.L.; Chen, X.Y.; Kong, Q.Y.; Wang, X.W.; Sun, Y.; Wen, S.; Liu, J. c-Myc downregulation: A critical molecular event in resveratrol-induced cell cycle arrest and apoptosis of human medulloblastoma cells. J. Neurooncol. 2006, 80, 123-131.

179. von Bueren, A.O.; Shalaby, T.; Rajtarova, J.; Stearns, D.; Eberhart, C.G.; Helson, L.; Arcaro, A.; Grotzer, M.A. Anti-proliferative activity of the quassinoid NBT-272 in childhood medulloblastoma cells. BMC Cancer 2007, 7, 19.

180. Castelletti, D.; Fiaschetti, G.; di Dato, V.; Ziegler, U.; Kumps, C.; de Preter, K.; Zollo, M.; Speleman, F.; Shalaby, T.; de Martino, D.; et al. The quassinoid derivative NBT-272 targets both the AKT and ERK signaling pathways in embryonal tumors. Mol. Cancer Ther. 2010, 9, 3145-3157.

181. Balasubramanian, S.; Hurley, L.H.; Neidle, S. Targeting G-quadruplexes in gene promoters: A novel anticancer strategy? Nat. Rev. Drug Discov. 2011, 10, 261-275. 
182. Shalaby, T.; von Bueren, A.O.; Hurlimann, M.L.; Fiaschetti, G.; Castelletti, D.; Masayuki, T.; Nagasawa, K.; Arcaro, A.; Jelesarov, I.; Shin-ya, K.; Grotzer, M. Disabling c-Myc in childhood medulloblastoma and atypical teratoid/rhabdoid tumor cells by the potent G-quadruplex interactive agent S2T1-6OTD. Mol. Cancer Ther. 2010, 9, 167-179.

183. Mu, J.; Wei, L.X. Telomere and telomerase in oncology. Cell. Res. 2002, 12, 1-7.

184. Bergers, G.; Brekken, R.; McMahon, G.; Vu, T.H.; Itoh, T.; Tamaki, K.; Tanzawa, K.; Thorpe, P.; Itohara, S.; Werb, Z.; Hanahan, D. Matrix metalloproteinase-9 triggers the angiogenic switch during carcinogenesis. Nature Cell. Biology 2000, 2, 737-744.

185. Hanahan, D.; Weinberg, R.A. The hallmarks of cancer. Cell 2000, 100, 57-70.

186. De Cian, A.; Lacroix, L.; Douarre, C.; Temime-Smaali, N.; Trentesaux, C.; Riou, J.F.; Mergny, J.L. Targeting telomeres and telomerase. Biochimie 2008, 90, 131-155.

187. Neidle, S.; Parkinson, G. Telomere maintenance as a target for anticancer drug discovery. Nat. Rev. Drug Discov. 2002, 1, 383-393.

188. Saretzki, G. Telomerase inhibition as cancer therapy. Cancer Lett. 2003, 194, 209-219.

189. Rossi, A.; Russo, G.; Puca, A.; La Montagna, R.; Caputo, M.; Mattioli, E.; Lopez, M.; Giordano, A.; Pentimalli, F. The antiretroviral nucleoside analogue Abacavir reduces cell growth and promotes differentiation of human medulloblastoma cells. Int. J. Cancer 2009, 125, 235-243.

190. Wang, Q.; Liu, J.Q.; Chen, Z.; Zheng, K.W.; Chen, C.Y.; Hao, Y.H.; Tan, Z. G-quadruplex formation at the 3 ' end of telomere DNA inhibits its extension by telomerase, polymerase and unwinding by helicase. Nucleic Acids Res. 2011, 39, 6229-6237.

191. Kramer, R.; Cohen, D. Functional genomics to new drug targets. Nat. Rev. Drug Discov. 2004, 3, 965-972.

192. Tan, D.S. Diversity-oriented synthesis: Exploring the intersections between chemistry and biology. Nat. Chem. Biol. 2005, 1, 74-84.

193. Neidle, S. Human telomeric G-quadruplex: The current status of telomeric G-quadruplexes as therapeutic targets in human cancer. Febs. J. 2010, 277, 1118-1125.

194. Phan, A.T. Human telomeric G-quadruplex: Structures of DNA and RNA sequences. FEBS J. 2010, 277, 1107-1117.

195. Neidle, S. The structures of quadruplex nucleic acids and their drug complexes. Curr. Opin. Struct. Biol. 2009, 19, 239-250.

196. Bejugam, M.; Sewitz, S.; Shirude, P.S.; Rodriguez, R.; Shahid, R.; Balasubramanian, S. Trisubstituted isoalloxazines as a new class of G-quadruplex binding ligands: Small molecule regulation of c-kit oncogene expression. J. Am. Chem. Soc. 2007, 129, 12926-12927.

197. Gunaratnam, M.; Greciano, O.; Martins, C.; Reszka, A.P.; Schultes, C.M.; Morjani, H.; Riou, J.F.; Neidle, S. Mechanism of acridine-based telomerase inhibition and telomere shortening. Biochem. Pharmacol. 2007, 74, 679-689.

198. Tahara, H.; Shin-Ya, K.; Seimiya, H.; Yamada, H.; Tsuruo, T.; Ide, T. G-Quadruplex stabilization by telomestatin induces TRF2 protein dissociation from telomeres and anaphase bridge formation accompanied by loss of the $3^{\prime}$ telomeric overhang in cancer cells. Oncogene 2006, 25, 1955-1966.

199. Yang, D.; Okamoto, K. Structural insights into G-quadruplexes: Towards new anticancer drugs. Future Med. Chem. 2010, 2, 619-646. 
200. Huppert, J.L.; Balasubramanian, S. G-quadruplexes in promoters throughout the human genome. Nucleic Acids Res. 2007, 35, 406-413.

201. Todd, A.K.; Johnston, M.; Neidle, S. Highly prevalent putative quadruplex sequence motifs in human DNA. Nucleic Acids Res. 2005, 33, 2901-2907.

202. Fernando, H.; Reszka, A.P.; Huppert, J.; Ladame, S.; Rankin, S.; Venkitaraman, A.R.; Neidle, S.; Balasubramanian, S. A conserved quadruplex motif located in a transcription activation site of the human c-kit oncogene. Biochemistry 2006, 45, 7854-7860.

203. Rankin, S.; Reszka, A.P.; Huppert, J.; Zloh, M.; Parkinson, G.N.; Todd, A.K.; Ladame, S.; Balasubramanian, S.; Neidle, S. Putative DNA quadruplex formation within the human c-kit oncogene. J. Am. Chem. Soc. 2005, 127, 10584-10589.

204. Cogoi, S.; Xodo, L.E. G-quadruplex formation within the promoter of the KRAS proto-oncogene and its effect on transcription. Nucleic Acids Res. 2006, 34, 2536-2549.

205. Lim, K.W.; Alberti, P.; Guedin, A.; Lacroix, L.; Riou, J.F.; Royle, N.J.; Mergny, J.L.; Phan, A.T. Sequence variant (CTAGGG)n in the human telomere favors a G-quadruplex structure containing a G.C.G.C tetrad. Nucleic Acids Res. 2009, 37, 6239-6248.

206. Palumbo, S.L.; Ebbinghaus, S.W.; Hurley, L.H. Formation of a unique end-to-end stacked pair of G-quadruplexes in the hTERT core promoter with implications for inhibition of telomerase by G-quadruplex-interactive ligands. J. Am. Chem. Soc. 2009, 131, 10878-10891.

207. Dai, J.; Chen, D.; Jones, R.A.; Hurley, L.H.; Yang, D. NMR solution structure of the major G-quadruplex structure formed in the human BCL2 promoter region. Nucleic Acids Res. 2006, 34, 5133-5144.

208. Sun, D.; Guo, K.; Rusche, J.J.; Hurley, L.H. Facilitation of a structural transition in the polypurine/polypyrimidine tract within the proximal promoter region of the human VEGF gene by the presence of potassium and G-quadruplex-interactive agents. Nucleic Acids Res. 2005, 33, 6070-6080.

209. De Armond, R.; Wood, S.; Sun, D.; Hurley, L.H.; Ebbinghaus, S.W. Evidence for the presence of a guanine quadruplex forming region within a polypurine tract of the hypoxia inducible factor 1alpha promoter. Biochemistry 2005, 44, 16341-16350.

210. Palumbo, S.L.; Memmott, R.M.; Uribe, D.J.; Krotova-Khan, Y.; Hurley, L.H.; Ebbinghaus, S.W. A novel G-quadruplex-forming GGA repeat region in the c-myb promoter is a critical regulator of promoter activity. Nucleic Acids Res. 2008, 36, 1755-1769.

211. Mathad, R.I.; Hatzakis, E.; Dai, J.; Yang, D. c-MYC promoter G-quadruplex formed at the 5'-end of NHE III1 element: Insights into biological relevance and parallel-stranded Gquadruplex stability. Nucleic Acids Res. 2011, 39, 9023-9033.

212. Yang, D.; Hurley, L.H. Structure of the biologically relevant G-quadruplex in the c-MYC promoter. Nucleosides Nucleotides Nucleic Acids 2006, 25, 951-968.

213. Yang, H.; Ma, V.P.; Chan, D.S.; He, H.Z.; Leung, C.H.; Ma, D.L. A cyclometallated iridium(III) complex as a c-myc G-quadruplex stabilizer and down-regulator of c-myc oncogene expression. Curr. Med. Chem. 2013, 20, 576-582.

214. Qin, Y.; Rezler, E.M.; Gokhale, V.; Sun, D.; Hurley, L.H. Characterization of the G-quadruplexes in the duplex nuclease hypersensitive element of the PDGF-A promoter and modulation of PDGF-A promoter activity by TMPyP4. Nucleic Acids Res. 2007, 35, 7698-7713. 
215. Xu, Y.; Sugiyama, H. Formation of the G-quadruplex and i-motif structures in retinoblastoma susceptibility genes (Rb). Nucleic Acids Res. 2006, 34, 949-954.

216. Collie, G.W.; Parkinson, G.N. The application of DNA and RNA G-quadruplexes to therapeutic medicines. Chem. Soc. Rev. 2011, 40, 5867-5892.

217. Eddy, J.; Maizels, N. Gene function correlates with potential for G4 DNA formation in the human genome. Nucleic Acids Res. 2006, 34, 3887-3896.

218. Shirude, P.S.; Ying, L.; Balasubramanian, S. Single molecule conformational analysis of the biologically relevant DNA G-quadruplex in the promoter of the proto-oncogene c-MYC. Chem. Commun. 2008, 2007-2009.

219. Simonsson, T.; Pecinka, P.; Kubista, M. DNA tetraplex formation in the control region of c-myc. Nucleic Acids Res. 1998, 26, 1167-1172.

220. Grotzer, M.A.; Castelletti, D.; Fiaschetti, G.; Shalaby, T.; Arcaro, A. Targeting Myc in pediatric malignancies of the central and peripheral nervous system. Curr. Cancer Drug Targets 2009, 9 , 176-188.

221. Fekete, A.; Kenesi, E.; Hunyadi-Gulyas, E.; Durgo, H.; Berko, B.; Dunai, Z.A.; Bauer, P.I. The guanine-quadruplex structure in the human c-myc gene's promoter is converted into B-DNA form by the human poly (ADP-ribose) polymerase-1. PLoS One 2012, 7, e42690.

222. Gonzalez, V.; Hurley, L.H. The c-MYC NHE III(1): Function and regulation. Annu. Rev. Pharmacol. Toxicol. 2010, 50, 111-129.

223. Siddiqui-Jain, A.; Grand, C.L.; Bearss, D.J.; Hurley, L.H. Direct evidence for a G-quadruplex in a promoter region and its targeting with a small molecule to repress c-MYC transcription. Proc. Natl. Acad. Sci. USA 2002, 99, 11593-11598.

224. Brooks, T.A.; Hurley, L.H. Targeting MYC Expression through G-Quadruplexes. Genes Cancer 2010, 1, 641-649.

225. Brooks, T.A.; Hurley, L.H. The role of supercoiling in transcriptional control of MYC and its importance in molecular therapeutics. Nat. Rev. Cancer 2009, 9, 849-861.

226. Liu, J.N.; Deng, R.; Guo, J.F.; Zhou, J.M.; Feng, G.K.; Huang, Z.S.; Gu, L.Q.; Zeng, Y.X.; Zhu, X.F. Inhibition of myc promoter and telomerase activity and induction of delayed apoptosis by SYUIQ-5, a novel G-quadruplex interactive agent in leukemia cells. Leukemia 2007, 21, $1300-1302$.

227. Ou, T.M.; Lu, Y.J.; Zhang, C.; Huang, Z.S.; Wang, X.D.; Tan, J.H.; Chen, Y.; Ma, D.L.; Wong, K.Y.; Tang, J.C.; Chan, A.S.; Gu, L.Q. Stabilization of G-quadruplex DNA and down-regulation of oncogene c-myc by quindoline derivatives. J. Med. Chem. 2007, 50, 1465-1474.

228. Nicoludis, J.M.; Miller, S.T.; Jeffrey, P.D.; Barrett, S.P.; Rablen, P.R.; Lawton, T.J.; Yatsunyk, L.A. Optimized end-stacking provides specificity of N-methyl mesoporphyrin IX for human telomeric G-quadruplex DNA. J. Am. Chem. Soc. 2012, 134, 20446-20456.

229. Folini, M.; Venturini, L.; Cimino-Reale, G.; Zaffaroni, N. Telomeres as targets for anticancer therapies. Expert Opin. Ther. Targets 2011, 15, 579-593.

230. Duchler, M. G-quadruplexes: Targets and tools in anticancer drug design. J. Drug Target. 2012, 20, 389-400. 
231. De Cian, A.; Cristofari, G.; Reichenbach, P.; De Lemos, E.; Monchaud, D.; Teulade-Fichou, M.P.; Shin-Ya, K.; Lacroix, L.; Lingner, J.; Mergny, J.L. Reevaluation of telomerase inhibition by quadruplex ligands and their mechanisms of action. Proc. Natl. Acad. Sci. USA 2007, 104, 17347-17352.

232. Shin-ya, K.; Wierzba, K.; Matsuo, K.; Ohtani, T.; Yamada, Y.; Furihata, K.; Hayakawa, Y.; Seto, H. Telomestatin, a novel telomerase inhibitor from Streptomyces anulatus. J. Am. Chem. Soc. 2001, 123, 1262-1263.

233. Moorhouse, A.D.; Haider, S.; Gunaratnam, M.; Munnur, D.; Neidle, S.; Moses, J.E. Targeting telomerase and telomeres: A click chemistry approach towards highly selective G-quadruplex ligands. Mol. Biosyst. 2008, 4, 629-642.

234. Sumi, M.; Tauchi, T.; Sashida, G.; Nakajima, A.; Gotoh, A.; Shin-Ya, K.; Ohyashiki, J.H.; Ohyashiki, K. A G-quadruplex-interactive agent, telomestatin (SOT-095), induces telomere shortening with apoptosis and enhances chemosensitivity in acute myeloid leukemia. Int. J. Oncol. 2004, 24, 1481-1487.

235. Nakajima, A.; Tauchi, T.; Sashida, G.; Sumi, M.; Abe, K.; Yamamoto, K.; Ohyashiki, J.H.; Ohyashiki, K. Telomerase inhibition enhances apoptosis in human acute leukemia cells: Possibility of antitelomerase therapy. Leukemia 2003, 17, 560-567.

236. Shammas, M.A.; Shmookler Reis, R.J.; Li, C.; Koley, H.; Hurley, L.H.; Anderson, K.C.; Munshi, N.C. Telomerase inhibition and cell growth arrest after telomestatin treatment in multiple myeloma. Clin. Cancer Res. 2004, 10, 770-776.

237. Miyazaki, T.; Pan, Y.; Joshi, K.; Purohit, D.; Hu, B.; Demir, H.; Mazumder, S.; Okabe, S.; Yamori, T.; Viapiano, M.; Shin-ya, K.; Seimiya, H.; Nakano, I. Telomestatin impairs glioma stem cell survival and growth through the disruption of telomeric G-quadruplex and inhibition of the proto-oncogene, c-Myb. Clin. Cancer Res. 2012, 18, 1268-1280.

238. Tauchi, T.; Shin-Ya, K.; Sashida, G.; Sumi, M.; Nakajima, A.; Shimamoto, T.; Ohyashiki, J.H.; Ohyashiki, K. Activity of a novel G-quadruplex-interactive telomerase inhibitor, telomestatin (SOT-095), against human leukemia cells: Involvement of ATM-dependent DNA damage response pathways. Oncogene 2003, 22, 5338-5347.

239. Kim, M.Y.; Vankayalapati, H.; Shin-Ya, K.; Wierzba, K.; Hurley, L.H. Telomestatin, a potent telomerase inhibitor that interacts quite specifically with the human telomeric intramolecular g-quadruplex. J. Am. Chem. Soc. 2002, 124, 2098-2099.

240. Tauchi, T.; Shin-ya, K.; Sashida, G.; Sumi, M.; Okabe, S.; Ohyashiki, J.H.; Ohyashiki, K. Telomerase inhibition with a novel G-quadruplex-interactive agent, telomestatin: In vitro and in vivo studies in acute leukemia. Oncogene 2006, 25, 5719-5725.

241. Tsai, Y.C.; Qi, H.; Lin, C.P.; Lin, R.K.; Kerrigan, J.E.; Rzuczek, S.G.; LaVoie, E.J.; Rice, J.E.; Pilch, D.S.; Lyu, Y.L.; Liu, L.F. A G-quadruplex stabilizer induces M-phase cell cycle arrest. J. Biol. Chem. 2009, 284, 22535-22543.

242. Fujimori, J.; Matsuo, T.; Shimose, S.; Kubo, T.; Ishikawa, M.; Yasunaga, Y.; Ochi, M. Antitumor effects of telomerase inhibitor TMPyP4 in osteosarcoma cell lines. J. Orthop. Res. 2011, 29, 1707-1711.

243. Kimura, T.; Kawai, K.; Fujitsuka, M.; Majima, T. Detection of the G-quadruplex-TMPyP4 complex by 2-aminopurine modified human telomeric DNA. Chem. Commun. 2006, 2006, 401-402. 
244. Mikami-Terao, Y.; Akiyama, M.; Yuza, Y.; Yanagisawa, T.; Yamada, O.; Kawano, T.; Agawa, M.; Ida, H.; Yamada, H. Antitumor activity of TMPyP4 interacting G-quadruplex in retinoblastoma cell lines. Exp. Eye Res. 2009, 89, 200-208.

245. Rha, S.Y.; Izbicka, E.; Lawrence, R.; Davidson, K.; Sun, D.; Moyer, M.P.; Roodman, G.D.; Hurley, L.; Von Hoff, D. Effect of telomere and telomerase interactive agents on human tumor and normal cell lines. Clin. Cancer Res. 2000, 6, 987-993.

246. Shammas, M.A.; Shmookler Reis, R.J.; Akiyama, M.; Koley, H.; Chauhan, D.; Hideshima, T.; Goyal, R.K.; Hurley, L.H.; Anderson, K.C.; Munshi, N.C. Telomerase inhibition and cell growth arrest by G-quadruplex interactive agent in multiple myeloma. Mol. Cancer Ther. 2003, 2, 825-833.

247. Zhou, J.M.; Zhu, X.F.; Lu, Y.J.; Deng, R.; Huang, Z.S.; Mei, Y.P.; Wang, Y.; Huang, W.L.; Liu, Z.C.; Gu, L.Q.; Zeng, Y.X. Senescence and telomere shortening induced by novel potent G-quadruplex interactive agents, quindoline derivatives, in human cancer cell lines. Oncogene 2006, 25, 503-511.

248. Zhou, W.J.; Deng, R.; Zhang, X.Y.; Feng, G.K.; Gu, L.Q.; Zhu, X.F. G-quadruplex ligand SYUIQ-5 induces autophagy by telomere damage and TRF2 delocalization in cancer cells. Mol. Cancer Ther. 2009, 8, 3203-3213.

249. Hampel, S.M.; Sidibe, A.; Gunaratnam, M.; Riou, J.F.; Neidle, S. Tetrasubstituted naphthalene diimide ligands with selectivity for telomeric G-quadruplexes and cancer cells. Bioorg. Med. Chem. Lett. 2010, 20, 6459-6463.

250. Gomez, D.; Aouali, N.; Renaud, A.; Douarre, C.; Shin-Ya, K.; Tazi, J.; Martinez, S.; Trentesaux, C.; Morjani, H.; Riou, J.F. Resistance to senescence induction and telomere shortening by a G-quadruplex ligand inhibitor of telomerase. Cancer Res. 2003, 63, 6149-6153.

251. Gomez, D.; Lemarteleur, T.; Lacroix, L.; Mailliet, P.; Mergny, J.L.; Riou, J.F. Telomerase downregulation induced by the G-quadruplex ligand 12459 in A549 cells is mediated by hTERT RNA alternative splicing. Nucleic Acids Res. 2004, 32, 371-379.

252. Kelland, L. Targeting the limitless replicative potential of cancer: The telomerase/telomere pathway. Clin. Cancer Res. 2007, 13, 4960-4963.

253. Kelland, L.R. Overcoming the immortality of tumour cells by telomere and telomerase based cancer therapeutics--current status and future prospects. Eur. J. Cancer 2005, 41, 971-979.

254. Riou, J.F.; Guittat, L.; Mailliet, P.; Laoui, A.; Renou, E.; Petitgenet, O.; Megnin-Chanet, F.; Helene, C.; Mergny, J.L. Cell senescence and telomere shortening induced by a new series of specific G-quadruplex DNA ligands. Proc. Natl. Acad. Sci. USA 2002, 99, 2672-2677.

255. Gunaratnam, M.; Green, C.; Moreira, J.B.; Moorhouse, A.D.; Kelland, L.R.; Moses, J.E.; Neidle, S. G-quadruplex compounds and cis-platin act synergistically to inhibit cancer cell growth in vitro and in vivo. Biochem. Pharmacol. 2009, 78, 115-122.

256. Collie, G.; Reszka, A.P.; Haider, S.M.; Gabelica, V.; Parkinson, G.N.; Neidle, S. Selectivity in small molecule binding to human telomeric RNA and DNA quadruplexes. Chem. Commun. 2009, 2009, 7482-7484.

257. Gowan, S.M.; Harrison, J.R.; Patterson, L.; Valenti, M.; Read, M.A.; Neidle, S.; Kelland, L.R. A G-quadruplex-interactive potent small-molecule inhibitor of telomerase exhibiting in vitro and in vivo antitumor activity. Mol. Pharmacol. 2002, 61, 1154-1162. 
258. Incles, C.M.; Schultes, C.M.; Kempski, H.; Koehler, H.; Kelland, L.R.; Neidle, S. A G-quadruplex telomere targeting agent produces p16-associated senescence and chromosomal fusions in human prostate cancer cells. Mol. Cancer Ther. 2004, 3, 1201-1206.

259. Phatak, P.; Cookson, J.C.; Dai, F.; Smith, V.; Gartenhaus, R.B.; Stevens, M.F.; Burger, A.M. Telomere uncapping by the G-quadruplex ligand RHPS4 inhibits clonogenic tumour cell growth in vitro and in vivo consistent with a cancer stem cell targeting mechanism. Br. J. Cancer 2007, 96, 1223-1233.

260. Read, M.; Harrison, R.J.; Romagnoli, B.; Tanious, F.A.; Gowan, S.H.; Reszka, A.P.; Wilson, W.D.; Kelland, L.R.; Neidle, S. Structure-based design of selective and potent G quadruplex-mediated telomerase inhibitors. Proc. Natl. Acad. Sci. USA 2001, 98, 4844-4849.

261. Cookson, J.C.; Dai, F.; Smith, V.; Heald, R.A.; Laughton, C.A.; Stevens, M.F.; Burger, A.M. Pharmacodynamics of the G-quadruplex-stabilizing telomerase inhibitor 3,11-difluoro-6,8, 13-trimethyl-8H-quino[4,3,2-kl]acridinium methosulfate (RHPS4) in vitro: Activity in human tumor cells correlates with telomere length and can be enhanced, or antagonized, with cytotoxic agents. Mol. Pharmacol. 2005, 68, 1551-1558.

262. Gavathiotis, E.; Heald, R.A.; Stevens, M.F.; Searle, M.S. Drug recognition and stabilisation of the parallel-stranded DNA quadruplex d(TTAGGGT)4 containing the human telomeric repeat. J. Mol. Biol. 2003, 334, 25-36.

263. Leonetti, C.; Amodei, S.; D'Angelo, C.; Rizzo, A.; Benassi, B.; Antonelli, A.; Elli, R.; Stevens, M.F.; D'Incalci, M.; Zupi, G.; Biroccio, A. Biological activity of the G-quadruplex ligand RHPS4 (3,11-difluoro-6,8,13-trimethyl-8H-quino[4,3,2-k1]acridinium methosulfate) is associated with telomere capping alteration. Mol. Pharmacol. 2004, 66, 1138-1146.

264. Leonetti, C.; Scarsella, M.; Riggio, G.; Rizzo, A.; Salvati, E.; D'Incalci, M.; Staszewsky, L.; Frapolli, R.; Stevens, M.F.; Stoppacciaro, A.; Mottolese, M.; Antoniani, B.; Gilson, E.; Zupi, G.; Biroccio, A. G-quadruplex ligand RHPS4 potentiates the antitumor activity of camptothecins in preclinical models of solid tumors. Clin. Cancer Res. 2008, 14, 7284-7291.

265. Rizzo, A.; Salvati, E.; Porru, M.; D'Angelo, C.; Stevens, M.F.; D'Incalci, M.; Leonetti, C.; Gilson, E.; Zupi, G.; Biroccio, A. Stabilization of quadruplex DNA perturbs telomere replication leading to the activation of an ATR-dependent ATM signaling pathway. Nucleic Acids Res. 2009, 37, 5353-5364.

266. Salvati, E.; Scarsella, M.; Porru, M.; Rizzo, A.; Iachettini, S.; Tentori, L.; Graziani, G.; D'Incalci, M.; Stevens, M.F.; Orlandi, A.; Passeri, D.; Gilson, E.; Zupi, G.; Leonetti, C.; Biroccio, A. PARP1 is activated at telomeres upon G4 stabilization: Possible target for telomere-based therapy. Oncogene 2010, 29, 6280-6293.

267. Cuenca, F.; Moore, M.J.; Johnson, K.; Guyen, B.; De Cian, A.; Neidle, S. Design, synthesis and evaluation of 4,5-di-substituted acridone ligands with high G-quadruplex affinity and selectivity, together with low toxicity to normal cells. Bioorg. Med. Chem. Lett. 2009, 19, 5109-5113.

268. Folini, M.; Pivetta, C.; Zagotto, G.; De Marco, C.; Palumbo, M.; Zaffaroni, N.; Sissi, C. Remarkable interference with telomeric function by a G-quadruplex selective bisantrene regioisomer. Biochem. Pharmacol. 2010, 79, 1781-1790. 
269. Huang, H.S.; Huang, K.F.; Li, C.L.; Huang, Y.Y.; Chiang, Y.H.; Huang, F.C.; Lin, J.J. Synthesis, human telomerase inhibition and anti-proliferative studies of a series of 2,7-bis-substituted amido-anthraquinone derivatives. Bioorg. Med. Chem. 2008, 16, 6976-6986.

270. Franceschin, M.; Rizzo, A.; Casagrande, V.; Salvati, E.; Alvino, A.; Altieri, A.; Ciammaichella, A.; Iachettini, S.; Leonetti, C.; Ortaggi, G.; Porru, M.; Bianco, A.; Biroccio, A. Aromatic core extension in the series of N-cyclic bay-substituted perylene G-quadruplex ligands: Increased telomere damage, antitumor activity, and strong selectivity for neoplastic over healthy cells. ChemMedChem 2012, 7, 2144-2154.

271. Micheli, E.; D'Ambrosio, D.; Franceschin, M.; Savino, M. Water soluble cationic perylene derivatives as possible telomerase inhibitors: The search for selective G-quadruplex targeting. Mini Rev. Med. Chem. 2009, 9, 1622-1632.

272. Rzuczek, S.G.; Pilch, D.S.; Liu, A.; Liu, L.; LaVoie, E.J.; Rice, J.E. Macrocyclic pyridyl polyoxazoles: Selective RNA and DNA G-quadruplex ligands as antitumor agents. J. Med. Chem. 2010, 53, 3632-3644.

273. Satyanarayana, M.; Kim, Y.A.; Rzuczek, S.G.; Pilch, D.S.; Liu, A.A.; Liu, L.F.; Rice, J.E.; LaVoie, E.J. Macrocyclic hexaoxazoles: Influence of aminoalkyl substituents on RNA and DNA G-quadruplex stabilization and cytotoxicity. Bioorg. Med. Chem. Lett. 2010, 20, 3150-154.

274. Liu, J.; Guo, L.; Yin, F.; Zheng, X.; Chen, G.; Wang, Y. Characterization and antitumor activity of triethylene tetramine, a novel telomerase inhibitor. Biomed. Pharmacother. 2008, 62, 480-485.

275. Lixia, G.; Fei, Y.; Jiajia, J.; Jianhui, L. Triethylene tetramine, a novel ligand of G-quadruplex, induces senescence of MCF-7 cells. Biotechnol. Lett. 2008, 30, 47-53.

276. De Cian, A.; Mergny, J.L. Quadruplex ligands may act as molecular chaperones for tetramolecular quadruplex formation. Nucleic Acids Res. 2007, 35, 2483-2493.

277. Tang, K.T.; Ho, L.T.; Jap, T.S.; Chang, T.C.; Ching, K.N.; Lam, H.C.; Wu, M.S.; Lee, S.P. Comparison of insulin secretion and insulin sensitivity between normal and impaired glucose tolerance subjects with normal fasting plasma glucose. Zhonghua Yi Xue Za Zhi. 1990, 46, 73-78.

278. Pennarun, G.; Granotier, C.; Gauthier, L.R.; Gomez, D.; Hoffschir, F.; Mandine, E.; Riou, J.F.; Mergny, J.L.; Mailliet, P.; Boussin, F.D. Apoptosis related to telomere instability and cell cycle alterations in human glioma cells treated by new highly selective G-quadruplex ligands. Oncogene 2005, 24, 2917-2928.

279. Guliaev, A.B.; Leontis, N.B. Cationic 5,10,15,20-tetrakis(N-methylpyridinium-4-yl)porphyrin fully intercalates at 5'-CG-3' steps of duplex DNA in solution. Biochemistry 1999, 38, 15425-15437.

280. Lee, Y.A.; Kim, J.O.; Cho, T.S.; Song, R.; Kim, S.K. Binding of meso-tetrakis( $N$ methylpyridium-4-yl)porphyrin to triplex oligonucleotides: Evidence for the porphyrin stacking in the major groove. J. Am. Chem. Soc. 2003, 125, 8106-8107.

281. Dixon, I.M.; Lopez, F.; Tejera, A.M.; Esteve, J.P.; Blasco, M.A.; Pratviel, G.; Meunier, B. A G-quadruplex ligand with 10000-fold selectivity over duplex DNA. J. Am. Chem. Soc. 2007, 129, 1502-1503.

282. Duan, W.; Rangan, A.; Vankayalapati, H.; Kim, M.Y.; Zeng, Q.; Sun, D.; Han, H.; Fedoroff, O.Y.; Nishioka, D.; Rha, S.Y.; Izbicka, E.; Von Hoff, D.D.; Hurley, L.H. Design and synthesis of fluoroquinophenoxazines that interact with human telomeric G-quadruplexes and their biological effects. Mol. Cancer Ther. 2001, 1, 103-120. 
283. Kim, M.Y.; Duan, W.; Gleason-Guzman, M.; Hurley, L.H. Design, synthesis, and biological evaluation of a series of fluoroquinoanthroxazines with contrasting dual mechanisms of action against topoisomerase II and G-quadruplexes. J. Med. Chem. 2003, 46, 571-583.

284. Drygin, D.; Siddiqui-Jain, A.; O'Brien, S.; Schwaebe, M.; Lin, A.; Bliesath, J.; Ho, C.B.; Proffitt, C.; Trent, K.; Whitten, J.P.; Lim, J.K.; Von Hoff, D.; Anderes, K.; Rice, W.G. Anticancer activity of CX-3543: A direct inhibitor of rRNA biogenesis. Cancer Res. 2009, 69, 7653-7661.

285. Bates, P.J.; Laber, D.A.; Miller, D.M.; Thomas, S.D.; Trent, J.O. Discovery and development of the G-rich oligonucleotide AS1411 as a novel treatment for cancer. Exp. Mol. Pathol. 2009, 86, $151-164$.

286. Fernando, H.; Rodriguez, R.; Balasubramanian, S. Selective recognition of a DNA G-quadruplex by an engineered antibody. Biochemistry 2008, 47, 9365-9371.

287. Ou, T.M.; Lu, Y.J.; Tan, J.H.; Huang, Z.S.; Wong, K.Y.; Gu, L.Q. G-quadruplexes: Targets in anticancer drug design. Chem.Med.Chem. 2008, 3, 690-713.

(C) 2013 by the authors; licensee MDPI, Basel, Switzerland. This article is an open access article distributed under the terms and conditions of the Creative Commons Attribution license (http://creativecommons.org/licenses/by/3.0/). 